\title{
Interactions of Silicon With Essential and Beneficial Elements in Plants
}

\author{
Jelena Pavlovic ${ }^{1 \dagger}$, Ljiljana Kostic ${ }^{1+}$, Predrag Bosnic ${ }^{1 \dagger}$, Ernest A. Kirkby ${ }^{2}$ and \\ Miroslav Nikolic ${ }^{1 *}$ \\ ${ }^{1}$ Institute for Multidisciplinary Research, University of Belgrade, Belgrade, Serbia, ${ }^{2}$ Faculty of Biological Sciences, Leeds \\ University, Leeds, United Kingdom
}

Silicon (Si) is not classified as an essential element for plants, but numerous studies have demonstrated its beneficial effects in a variety of species and environmental conditions, including low nutrient availability. Application of Si shows the potential to increase nutrient availability in the rhizosphere and root uptake through complex mechanisms, which still remain unclear. Silicon-mediated transcriptional regulation of

OPEN ACCESS

Edited by:

Francisco Javier Romera, University of Córdoba, Spain

Reviewed by:

Joerg Schaller,

Leibniz Center for Agricultural Landscape Research (ZALF),

Germany

Rivka Elbaum,

The Hebrew University of Jerusalem,

Israel

*Correspondence:

Miroslav Nikolic

mnikolic@imsi.bg.ac.rs

tThese authors have contributed equally to this work and share first authorship

Specialty section:

This article was submitted to Plant Nutrition,

a section of the journal Frontiers in Plant Science

Received: 19 April 2021 Accepted: 27 May 2021

Published: 23 June 2021

Citation:

Pavlovic J, Kostic L, Bosnic P, Kirkby EA and Nikolic M (2021) Interactions of Silicon With Essential and Beneficial Elements in Plants.

Front. Plant Sci. 12:697592.

doi: 10.3389/fp/s.2021.697592 element transporters for both root acquisition and tissue homeostasis has recently been suggested as an important strategy, varying in detail depending on plant species and nutritional status. Here, we summarize evidence of Si-mediated acquisition, uptake and translocation of nutrients: nitrogen $(\mathrm{N})$, phosphorus $(\mathrm{P})$, potassium $(\mathrm{K})$, calcium $(\mathrm{Ca})$, magnesium $(\mathrm{Mg})$, sulfur $(\mathrm{S})$, iron $(\mathrm{Fe})$, zinc $(\mathrm{Zn})$, manganese $(\mathrm{Mn})$, copper $(\mathrm{Cu})$, boron $(\mathrm{B})$, chlorine $(\mathrm{Cl})$, and nickel $(\mathrm{Ni})$ under both deficiency and excess conditions. In addition, we discuss interactions of Si-with beneficial elements: aluminum (Al), sodium $(\mathrm{Na})$, and selenium $(\mathrm{Se})$. This review also highlights further research needed to improve understanding of Si-mediated acquisition and utilization of nutrients and vice versa nutrient status-mediated Si acquisition and transport, both processes which are of high importance for agronomic practice (e.g., reduced use of fertilizers and pesticides).

Keywords: silicon, nutrients, beneficial elements, deficiency, toxicity, transporters

\section{INTRODUCTION}

Silicon ( $\mathrm{Si}$ ) is the second most abundant element (after oxygen) in the Earth's crust, mainly occurring as various silicate minerals in most soils. The concentration of the plant-available form of $\mathrm{Si}$ in soil solutions, monosilicic acid $\left(\mathrm{H}_{4} \mathrm{SiO}_{4}\right)$, varies between 0.1 and $0.6 \mathrm{mM}$, which is about two orders of magnitude higher than the concentrations of phosphorus (P) (Yan et al., 2018). Silicon in taken up and translocated through the plant to be deposited as $\mathrm{SiO}_{2}$ phytoliths in the lumen, cell walls and intercellular spaces (see Hodson and Evans, 2020). However, plants species differ greatly in their ability to accumulate $\mathrm{Si}$ with values ranging from $0.1 \%$ to $10 \% \mathrm{Si}$ on a dry weight basis (Epstein, 1994, 1999). Consequently, some plant species are minimally affected by Si fertilization compared to others (Coskun et al., 2019). This variation among species can be explained by different expression and functionality of Si transporters (see "Essential and Beneficial Element Status Affects Silicon Uptake and Distribution" section, below).

The essentiality of Si for plants has been the matter of a long debate dating back to the 19th century (e.g., J. von Sachs versus E. Wolff and C. Kreuzhage, see Sreenivasan, 1934; Katz et al., 2021). It is now reasonably well established that $S i$ is essential for only a few species of plants, the 


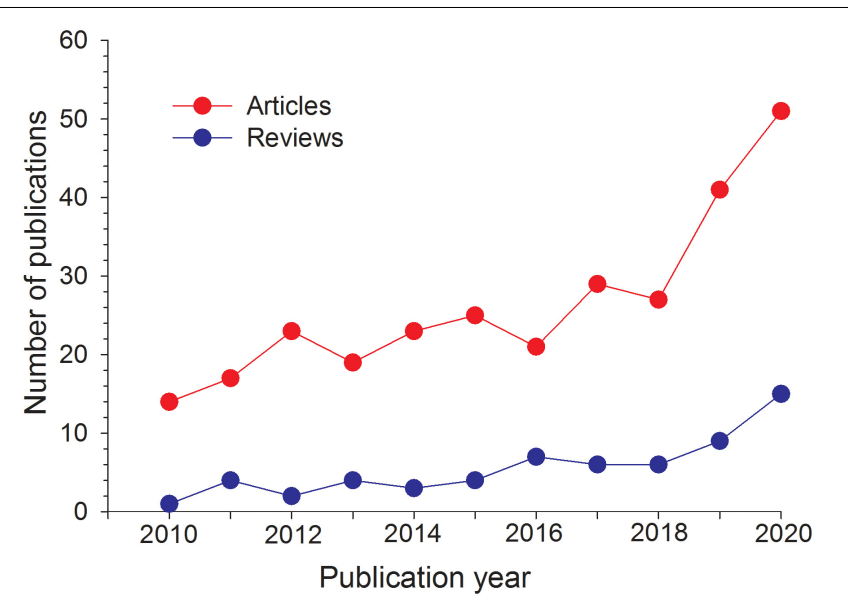

FIGURE 1 | Number of publications related to silicon in plants from 2010 to 2020, based on Scopus search with the title words: "Silicon" or "Silicate" and "Plants," refined to "Agricultural and Biological Sciences" (March, 2021). Total number of publications: 351; research articles: 290; reviews: 61.

silicophiles, high in Si concentration (see Marschner, 2012; Hodson and Evans, 2020). However, its classification as a beneficial element has been recognized for more than 50 years by those teaching and researching in plant nutrition (e.g., Mengel and Kirkby, 2001; Epstein and Bloom, 2008; Marschner, 2012). Numerous more recent studies, have confirmed its beneficial effects in a variety of species growing under a wide range of environmental conditions as reviewed by, e.g., Epstein (1994, 1999), Ma (2004); Liang et al. (2007) and Debona et al. (2017). This overwhelming evidence together with studies of Si transporters in plants and yield benefits of Si fertilization of crops probably eventually led the International Plant Nutrition Institute (IPNI) to upgrade Si from complete omission to a listing as "beneficial substance" in 2015 (Coskun et al., 2019). Indeed, as far as we are aware, Si appears to be the only known element that effectively alleviates both biotic (pathogens and pests) and abiotic (e.g., drought, salinity, heavy metals, UV irradiation, nutrient imbalance) stresses in many plant species. On the other hand, its physiologically versatile mode of action, regardless of the stress, is still uncertain and has recently been debated by Coskun et al. (2019). Interestingly, the ability of Si to alleviate different stresses has been confirmed even in species with a low $\mathrm{Si}$ accumulation potential, such as tomato (Hoffmann et al., 2020; Sun et al., 2020).

The past decade has seen a considerable increase in knowledge of the role of Si in plant biology and agriculture, as illustrated by the rapidly increasing number of both research and review articles (Figure 1), including recent special topics or issues devoted to $\mathrm{Si}$ in plants in peer-reviewed international journals (e.g., Frontiers in Plant Science, Journal of Experimental Botany, Plants). In general, most of the recent Si-related reviews deal with cycling and mobility of Si in soil, transport of Si (including $\mathrm{Si}$ transporters) in plants and on its role in biotic and/or abiotic stresses, while only a few focus on the role of $\mathrm{Si}$ on alleviating deficiency of nutrients (Herandez-Apaolaza, 2014; Ali et al., 2020).
This review attempts to summarize current evidence of interactions of $\mathrm{Si}$ with essential (nutrients) and beneficial elements in various crop species. We consider not only the ways in which Si supply affects rhizosphere mobility, uptake and transport of nutrient elements under different environmental conditions, but also the influence of plant nutrient status on the acquisition and transport of Si itself. Here we have not focused on Si chemistry and interactions of Si with other elements in soil mainly because this issue has already been updated in the review of Schaller et al. (2021) and also because of lack of evidence for direct mobilization of elements by $\mathrm{Si}$ in agricultural soils, with exception of peatlands (Reithmaier et al., 2017; Hömberg et al., 2020). After much deliberation we decided to base this review on individual elements rather than processes (e.g., rhizosphere acquisition, uptake, transport, utilization), taking the view that this approach would be more conducive to the reader and to finding information of interest. Finally, by comparative analysis of the literature describing both direct and indirect effects of $\mathrm{Si}$ in nutrient acquisition and utilization, we suggest research directions to elucidate how $\mathrm{Si}$ functions to support plants to overcome nutrient and beneficial element disorders, processes which urgently need to be explored experimentally and their implications for agricultural practice advanced.

\section{INTERACTIONS OF SILICON WITH MACRONUTRIENTS}

\section{Nitrogen}

Application of Si positively affects almost all aspects of nitrogen (N) nutrition, i.e., uptake, assimilation, and remobilization (Detmann et al., 2012; Wu et al., 2017; Haddad et al., 2018; Gou et al., 2020). This beneficial effect of Si on overall plant performance has been established under low, optimal, and excessive $\mathrm{N}$ supply. In addition to a direct effect on $\mathrm{N}$ metabolism, Si supply induces changes in carbon (C) and P stoichiometry in shoots (Schaller et al., 2012; Neu et al., 2017; Deus et al., 2020) and increases nutrient acquisition by roots (Barreto et al., 2017), which in turn can contribute to improving $\mathrm{N}$ utilization within plant tissues. Plant species and genotypes preferentially utilize different mineral $\mathrm{N}$ sources $\left(\mathrm{NO}_{3}{ }^{-}\right.$or $\mathrm{NH}_{4}{ }^{+}$), and show substantial variation in strategies to cope with $\mathrm{N}$ imbalance (Esteban et al., 2016). This may explain the high variation in interactions between $\mathrm{Si}$ and $\mathrm{N}$ observed in different plant species.

Increased $\mathrm{N}$ uptake under suboptimal $\mathrm{N}$ supply mediated by $\mathrm{Si}$ has been reported in different plant species, e.g., cowpea (Vigna unguiculata) (Mali and Aery, 2008a), maize (Zea mays) (Mabagala et al., 2020), rice (Oryza sativa) (Pati et al., 2016; Cuong et al., 2017; Deus et al., 2020). Increased tissue concentration of $\mathrm{N}$ has been attributed to enhanced $\mathrm{N}_{2}$ fixation (Mali and Aery, 2008a), increased $\mathrm{N}$ availability in soil, transcriptional up-regulation of genes involved in $\mathrm{N}$ uptake (Haddad et al., 2018; see Table 1), and enhanced transport efficiency (Sheng et al., 2018). Up-regulation of genes encoding $\mathrm{NO}_{3}{ }^{-}$transporters (BnaNTR2.1 and BnaNTR1.1) was proposed as an important strategy to overcome $\mathrm{N}$ deficiency in rapeseed (Brassica napus). Moreover, Si supplementation 


\begin{tabular}{|c|c|c|c|c|c|}
\hline Conditions & Plant species & Localization/direction/form/function & Transporter genes & Expression pattern by $\mathrm{Si}$ & References \\
\hline Low N & Rapeseed & Root/influx/nitrate/uptake & $\begin{array}{l}\text { BnNRT1.1, } \\
\text { BnNRT2.1 }\end{array}$ & Up-regulated & Haddad et al., 2018 \\
\hline High N & Rice & $\begin{array}{l}\text { Root/influx/ammonium/uptake } \\
\text { Root/influx/nitrate/uptake }\end{array}$ & $\begin{array}{l}\text { OSAMT1;1 } \\
\text { OsNTR1.1 }\end{array}$ & Down-regulated & Wu et al., 2017 \\
\hline Low $P$ & Wheat & Root/influx/phosphate/uptake & $\begin{array}{l}\text { TаPHT1;1, } \\
\text { TaPHT1;2 }\end{array}$ & Up-regulated & Kostic et al., 2017 \\
\hline High P & Rice & Root/influx/phosphate/uptake & OsPHT1;6 & Down-regulated & Hu et al., 2018 \\
\hline Low K & Sorghum & $\begin{array}{l}\text { Root cortex/influx } / \mathrm{K}^{+} / \text {xylem unloading } \\
\text { Root cortex/efflux/ } / \mathrm{K}^{+} / \text {xylem loading }\end{array}$ & $\begin{array}{l}\text { SbHAK5, SbAKT1 } \\
\text { SbSKOR1, } \\
\text { SbSKOR2 }\end{array}$ & $\begin{array}{l}\text { Down-regulated } \\
\text { Up-regulated }\end{array}$ & Chen et al., 2016b \\
\hline Low $S$ & Rice & Root/influx/sulfate/uptake & $\begin{array}{l}\text { OSSULTR1;1 } \\
\text { OsSULTR1;2 } \\
\text { OsSULTR2;1 } \\
\text { OsSULTR2;2 }\end{array}$ & $\begin{array}{l}\text { Down-regulated (up to } 3 \mathrm{~d} \text { of } \mathrm{S} \text { deficiency) } \\
\text { Down-regulated } \\
\text { Down-regulated (from } 1 \text { to } 3 \mathrm{~d} \text { of } \mathrm{S} \text { deficiency) } \\
\text { Down-regulated ( } 15 \mathrm{~d} \text { of } \mathrm{S} \text { deficiency) }\end{array}$ & Réthoré et al., 2020 \\
\hline \multirow[t]{3}{*}{ Low Fe } & Cucumber & Root/influx/Fe'2+/uptake & CsIRT1 & Up-regulated (3 d of Si supply) & Pavlovic et al., 2013 \\
\hline & & Leaf/efflux/Fe(II)-complex/phloem mobilization & CSYSL1 & Up-regulated & Pavlovic et al., 2016 \\
\hline & Barley & Root/influx/Fe(III)-complex/uptake & HvYS1 & Up-regulated (5 h of Si supply) & Nikolic et al., 2019 \\
\hline High Mn & Rice & Root/influx/Mn²+/uptake & OsNramp5 & Down-regulated & Che et al., 2016 \\
\hline \multirow[t]{3}{*}{ High Cu } & Arabidopsis & Root/influx/Cu' ${ }^{2+} /$ uptake & $\begin{array}{l}\text { AtCOPT1, } \\
\text { AtHMA5 }\end{array}$ & Down-regulated & Li J. et al., 2008 \\
\hline & Rice & $\begin{array}{l}\text { Root/influx/metal ions/translocation } \\
\text { Root/efflux/metal ions/sequestration }\end{array}$ & $\begin{array}{l}\text { OSHMA2 } \\
\text { OSHMA3 }\end{array}$ & $\begin{array}{l}\text { Down-regulated } \\
\text { Down-regulated }\end{array}$ & Kim et al., 2014 \\
\hline & Tobacco & Root/influx/ $\mathrm{Cu}^{2+} /$ uptake & NtCOPT1 & Down-regulated & Flora et al., 2019 \\
\hline High Zn & Rice & Root/influx/Zn²+/uptake & OsZIP1 & Down-regulated & Huang and Ma, 2020 \\
\hline High B & Barley & Leaf/efflux $/ \mathrm{H}_{3} \mathrm{BO}_{3} /$ export out of symplast & HVBOR2 & Up-regulated & Akcay and Erkan, 2016 \\
\hline High $\mathrm{Na}$ & Maize & $\begin{array}{l}\text { Root/efflux/ } / \mathrm{Na}^{+} / \text {export and xylem loading } \\
\text { Root/influx/ } \mathrm{Na}^{+} / \text {uptake } \\
\text { Leaf/influx/ } \mathrm{Na}^{+} / \text {vacuolar sequestration }\end{array}$ & $\begin{array}{l}Z m S O S 1, Z m S O S 2 \\
Z m H K T 1 \\
Z m N H X\end{array}$ & $\begin{array}{l}\text { Up-regulated } \\
\text { Down-regulated } \\
\text { Up-regulated }\end{array}$ & Bosnic et al., 2018 \\
\hline
\end{tabular}

TABLE 1| Evidence for Si-mediated expression of genes encoding tranter 
increased expression of BnaNTR2.1 even before imposition of $\mathrm{N}$ starvation. In addition to the effect on gene expression, it has been suggested that $\mathrm{Si}$ increases the efficiency of the $\mathrm{NH}_{4}{ }^{+}$ transporter (OsAMT) without up-regulation of OsAMT (Sheng et al., 2018). On the other hand, enhanced rate of $\mathrm{N}$ assimilation has been proposed as another Si-mediated mechanism to alleviate $\mathrm{N}$ starvation ( $\mathrm{Wu}$ et al., 2017). In rice grown at low $\mathrm{N}$ supply, the relative expressions of N-uptake genes (OsNTR1.1 and $O s A M T 1 ; 1)$ were unaffected or even down-regulated by $\mathrm{Si}$ supply, whereas $\mathrm{N}$-assimilation genes (OsGS2, OsFd-GOGAT, OsNADH-GOGAT2, OsGDH2, and OsNR1) were up-regulated (Wu et al., 2017). Even in non-stressed rice with an adequate $\mathrm{N}$ supply, Si nutrition was shown to modulate the flux from 2oxoglutarate into amino acid metabolism (Detmann et al., 2012). However, the exact mechanisms by which $\mathrm{Si}$ induces change in $\mathrm{N}$ metabolism still remain unknown. One explanation could be that $\mathrm{Si}$ mediates increase in cytokinin activity in the leaf $\mathrm{N}$ source/sink balance via the increased expression of the gene CWINV1 encoding $\beta$-fructofuranosidase, insoluble isoenzyme 1 (Markovich et al., 2017).

Silicon fertilization is known to improve $\mathrm{N}$ use efficiency and agronomic parameters of crops (yield and nutritional value) as observed in the long-term experiments in rice (Cuong et al., 2017), maize (Mabagala et al., 2020), rapeseed (Laine et al., 2019), and wheat (Triticum aestivum) (Neu et al., 2017). Although the underlying mechanism has not been studied in detail, it has been demonstrated that Si-induced biosynthesis of amino acids and remobilization of $\mathrm{N}$ (Detmann et al., 2012) can partially explain this phenomenon. Theoretically, remobilization of $\mathrm{N}$ (mainly in amino-acids forms) from storage pools in vegetative organs to the grains is considered as one of the major factors regulating high seed yields (Tegeder and Masclaux-Daubresse, 2017). Another proposed effect of Si might be alteration of C:N:P stoichiometry (Schaller et al., 2012; Neu et al., 2017; Deus et al., 2020). The science underpinning these studies is that in $\mathrm{Si}$ accumulator plants especially (e.g., rice, grasses and sugarcane), Si might partially replace $\mathrm{C}$ in shoot tissues to stabilize function and enhance photosynthesis thereby changing C:N:P stoichiometry. The highly beneficial effects of partial replacement of $\mathrm{C}$ by $\mathrm{Si}$ have recently been shown very clearly in a pot experiment with soil applied Si to sugarcane (Frazāo et al., 2020). Replacement of $\mathrm{C}$ by $\mathrm{Si}$ induced lower plant $\mathrm{C}$ concentration and was associated with greater biomass production resulting from higher rates of $\mathrm{N}$ and $\mathrm{P}$ uptake and accumulation and enhanced rates of photosynthesis. Considering that Si incorporation into vegetative tissues is bioenergetically cheaper than the formation of structural C compounds, plants might well benefit from altered C:N stoichiometry, especially under limited $\mathrm{N}$ supply (Neu et al., 2017).

Enhanced growth of Si-fed plants exposed to high $\mathrm{N}$ concentration was often attributed to increased photosynthetic efficiency, antioxidant capacity and improved water status (Barreto et al., 2017; Viciedo et al., 2019; Campos et al., 2020). However, responses to Si application differ even among cultivars of the same species (Barreto et al., 2017, 2021; Campos et al., 2020). In particular, supply of $\mathrm{Si}$ is of importance for the high yielding cultivation systems with dense planting and large application doses of $\mathrm{N}$ fertilizers (Liang et al., 2015). Under such conditions, excess $\mathrm{N}$ causes lodging, mutual shading and susceptibility to biotic stresses. Recent evidence suggests a new role of Si in reducing $\mathrm{N}$ uptake (Wu et al., 2017), optimization of $\mathrm{N}$ assimilation (Gou et al., 2020), or increased uptake of cations (Barreto et al., 2017) under high $\mathrm{N}$ supply. In rice exposed to high N supply, Si primarily affected N uptake genes (OsNTR1.1 and OsAMT1;1), reducing their expression level and therefore limiting $\mathrm{N}$ uptake (Wu et al., 2017). Apart from OsGS1, none of the genes involved in $\mathrm{N}$ assimilation were affected by $\mathrm{Si}$ nutrition under $\mathrm{N}$ excess (Wu et al., 2017). A possible explanation for the down-regulation of $\mathrm{N}$-uptake genes by $\mathrm{Si}$ is increased cytokinin level (Kiba et al., 2011; Barreto et al., 2021), however, this proposal needs to be supported by further experimental evidence. By contrast, increased activity of $\mathrm{N}$-assimilation enzymes (NR, NiR, GS and GOGAT, and NADH-GDH) was suggested as a key factor of Si-mediated alleviation of nitrate toxicity in cucumber (Cucumis sativus) cv. Jinyou 1 (Gou et al., 2020). Supply of Si in cauliflower (Brassica oleracea var. Botrytis) and broccoli (Brassica oleracea var. Italica) exposed to $\mathrm{NH}_{4}{ }^{+}$toxicity increased uptake of $\mathrm{K}^{+}$(Barreto et al., 2017), which activates enzymes GS and $\mathrm{GDH}$ that convert ammonium to amino acids and therefore mitigate tissue accumulation of toxic $\mathrm{NH}_{4}{ }^{+}$(Sarasketa et al., 2014; Esteban et al., 2016).

\section{Phosphorus}

The influence of Si on P nutrition has been extensively studied. Evidence suggests that Si plays a significant role in $\mathrm{P}$ nutrition, but the precise nature of that role still remains unclear; in particular, experimental evidence at molecular or protein level is scarce. So far, an alleviating effect of Si under P limiting conditions has been reported in wheat (Kostic et al., 2017; Neu et al., 2017), maize (Owino-Gerroh and Gascho, 2005), tomato (Solanum lycopersicum) (Zhang et al., 2019), rice (Ma and Takahashi, 1990; Pati et al., 2016; Hu et al., 2018) and potato (Solanum tuberosum) (Soltani et al., 2017; Soratto et al., 2019). Two major mechanisms of Si-mediated alleviation of P deficiency are proposed: (1) increased root uptake and (2) enhanced utilization of $\mathrm{P}$ within the plant tissues. Increased $\mathrm{P}$ uptake followed by soil Si fertilization has widely been reported (Owino-Gerroh and Gascho, 2005; Neu et al., 2017; Zhang et al., 2019). Silicon can increase $\mathrm{P}$ availability in soil, through $\mathrm{pH}$ changes, decreased $\mathrm{P}$ sorption by soil minerals, due to competition between $\mathrm{P}$ and $\mathrm{Si}$ (as depending on Si speciation in soil solution) or by changes in the dynamics of the microbial community (e.g., P-mobilizing microorganisms) (Owino-Gerroh and Gascho, 2005; Li et al., 2019; Schaller et al., 2019, 2021). However, the effect of Si on soil availability of $\mathrm{P}$ is dependent on soil type, mineralogical and microbial composition, $\mathrm{pH}$, as well as on type and amount of $\mathrm{Si}$ fertilizers (Hu et al., 2021). In addition, some Si fertilizers increase soil $\mathrm{pH}$ and thus eradicate the rhizotoxic effect of $\mathrm{Al}^{3+}$ in acid low $\mathrm{P}$ soils, thereby restoring overall root acquisition potential (Kostic et al., 2017).

On the other hand, the effect of $\mathrm{Si}$ on increased gene expression relating to inorganic $\mathrm{P}(\mathrm{Pi})$ uptake has been demonstrated in wheat (Kostic et al., 2017). In an acid low P soil, Si up-regulated genes encoding Pi transporters (TaPHT1;1 
and TaPHT1;2) and consequently increased Pi uptake. The effect of Si on up-regulation of transcript levels of Pi transporters was significantly greater than the effect of liming, suggesting that the ameliorative Si effect could not simply be attributed to Siinduced $\mathrm{pH}$ correction and increased $\mathrm{P}$ availability in soil. Silicon also stimulated root $\mathrm{Pi}$ acquisition by increasing the exudation of carboxylates (Kostic et al., 2017), although the effect of exuded carboxylates on P-mobilization in the soil is still controversial (Wang et al., 2016).

Improved internal $\mathrm{P}$ utilization as a response to $\mathrm{Si}$ supplementation in a low $\mathrm{P}$ environment was observed in rice and potato (Ma and Takahashi, 1990; Soratto et al., 2019). In rice, $\mathrm{Si}$ application resulted in decreased $\mathrm{Fe}$ and $\mathrm{Mn}$ uptake, while P uptake was unaffected (Ma and Takahashi, 1990). Given the high affinity of phosphates to metals such as Fe and Mn, the internal availability of $\mathrm{P}$ in plants may be affected by levels of these metals when $\mathrm{P}$ concentration is low (Ma and Takahashi, 1990). The influence of Si on Fe and Mn uptake is discussed in detail in "Interactions of Silicon with Micronutrients" section, below. Results for Si application to potato on a soil low in $\mathrm{P}$ were similar to those for rice. Si did not increase total P uptake, but concentrations of soluble inorganic $\mathrm{P}$ and total soluble $P$ of the leaves were enhanced (Soratto et al., 2019). Soluble inorganic $\mathrm{P}$ is the main plant $\mathrm{P}$ reserve and it is tightly regulated. Plants have developed a series of coordinated responses to conserve, recycle, and remobilize internal inorganic $\mathrm{P}$ to maintain P homeostasis (Chiou and Lin, 2011). The increase in soluble inorganic $\mathrm{P}$ concentration in leaves as a response to $\mathrm{Si}$ application therefore indicates that $\mathrm{Si}$ may play a role in maintenance of plant growth under low $\mathrm{P}$ availability (Soratto et al., 2019).

Excessive $\mathrm{P}$ levels in soil disturb plant growth and reduce food quality (Zhang et al., 2015; Nikolic et al., 2016). The Simediated decrease in $\mathrm{P}$ uptake under excessive $\mathrm{P}$ supply has been observed in several plant species such as rice ( $\mathrm{Hu}$ et al., 2018), soybean (Glycine max) (Miyake and Takahashi, 1985), strawberry (Fragaria ananassa) (Miyake and Takahashi, 1986), and cucumber (Marschner et al., 1990). This decrease is often attributed to the formation of physical apoplastic barriers by $\mathrm{Si}$ deposition in the root thereby decreasing $\mathrm{P}$ uptake (Ma, 2004). The effect of $\mathrm{Si}$ in regulating root $\mathrm{Pi}$ transporters was demonstrated, for the first time in rice by $\mathrm{Hu}$ et al. (2018). Under excessive P supply, Si amendment decreased expressions level of OsPHT1;6 and consequently decreased Pi uptake. The importance of $\mathrm{Si}$ accumulation in shoots on $\mathrm{P}$ uptake was elegantly demonstrated by comparing expression levels of OsPHT1;6 and $\mathrm{P}$ accumulation between wild type (WT) rice cultivar Oochikara and a rice mutant $l$ sil defective in the Lsi1 transporter for Si uptake (Hu et al., 2018).

\section{Potassium}

The interaction of $\mathrm{Si}$ with potassium $(\mathrm{K})$ in plants has been less well investigated than that with $\mathrm{N}$ and $\mathrm{P}$, although many studies have reported that $\mathrm{Si}$ can affect tissue $\mathrm{K}$ concentration under stress conditions such as salinity, drought or $\mathrm{N}$ excess (Kaya et al., 2006; Barreto et al., 2017; Yan et al., 2021b). Over the past decade, an increasing number of studies have focused on the direct effect of Si on K-deprived plants (Miao et al., 2010; Chen et al., 2016a,b; Hosseini et al., 2017; Buchelt et al., 2020; dos Santos Sarah et al., 2021). Increased uptake of $\mathrm{K}$ and restored physiological performance impaired by $\mathrm{K}$ deficiency has been reported as the main beneficial role of $\mathrm{Si}$ in K-deficient plants. In soybean and some forage crops (Panicum maximum and Brachiaria ruziziensis $\times$ Brachiaria brizanth), $\mathrm{Si}$ supplementation resulted in higher $\mathrm{K}$ concentration in leaves (Miao et al., 2010; Buchelt et al., 2020). In addition, Si also alleviated K-deficiency-induced membrane lipid peroxidation and oxidative stress by modulating antioxidant enzymes (Miao et al., 2010; Chen et al., 2016a).

Increased $\mathrm{K}$ uptake by $\mathrm{Si}$ supplied rice plants grown under saline conditions may possibly be explained by Si-mediated stimulation of $\mathrm{H}^{+}$-ATPase activity (Liang et al., 2003) or upregulation of $\mathrm{K}^{+}$transporter genes, i.e., OsHAK5, OsAKT1, and OsSKOR by Si (Yan et al., 2021b). On the other hand, in K-deprived maize and sorghum, Si supplementation did not increase $\mathrm{K}$ uptake but restored physiological activity commonly impaired by K deficit, i.e., water use efficiency and photosynthesis (Chen et al., 2016b; dos Santos Sarah et al., 2021). High xylem $\mathrm{K}^{+}$concentration reduces osmotic potential and thus contributes to xylem hydraulic conductance (Zwieniecki et al., 2001; Nardini et al., 2010). Chen et al. (2016b), showed that increased $\mathrm{K}^{+}$ concentration in the xylem sap of Si-fed plants was accompanied by up-regulated transcript levels of SKOR genes (SKOR1 and $S K O R 2)$ mediating $\mathrm{K}$ secretion from root cortex cells into the xylem and down-regulated transcript levels of AKT1 and HAK5 (Table 1) to maintain high $\mathrm{K}$ in the xylem. The authors propose that $\mathrm{Si}$ plays a role in plant signaling regulation under K-deficient stress, but clear evidence of this is still lacking. In relation to drought stress, Hosseini et al. (2017) investigated the effects of combined K deficiency and PEG-induced osmotic stress in barley (Hordeum vulgare). Since Si did not did not have a direct ameliorative effect on K deficiency, the authors suggest that the beneficial role of $\mathrm{Si}$ appears most likely mediated by abscisic acid (ABA) homeostasis and increased activity of cytokinin isopentenyl adenine.

\section{Calcium}

Different effects of Si on calcium (Ca) uptake and accumulation are reported in the literature depending on plant species, experimental conditions, stress type, and amount of Si applied. Several studies have reported that Si promotes Ca uptake in various crops grown under optimal conditions (Mali and Aery, 2008b; Gottardi et al., 2012; Greger et al., 2018), or in plants exposed to various forms of stress, as for instance in maize grown under drought stress (Kaya et al., 2006). By contrast, other studies suggested that Si does not affect (Cooke and Leishman, 2016) or even decreases Ca accumulation (Ma and Takahashi, 1993; Brackhage et al., 2013; Jang et al., 2018). Moreover, a progressive decline in tissue $\mathrm{Ca}$ accumulation with increasing Si supply has been demonstrated in rice and common reed (Phragmites australis) (Brackhage et al., 2013; Jang et al., 2018). However, these studies were not directly focused on the Si effect in Ca-deficient plants. Decreased $\mathrm{Ca}$ accumulation in response to $\mathrm{Si}$ application can be attributed to lowered transpiration 
caused by deposition of $\mathrm{Si}$ in the leaves ( $\mathrm{Ma}$ and Takahashi, 1993), reduced $\mathrm{Ca}^{2+}$ uptake due to biosilicification of root structures (Fleck et al., 2015) and Si-Ca interaction in the growing media or apoplast (Dishon et al., 2011). Recently, Bosnic et al. (2019c) reported that high Si supply may also decrease activity of $\mathrm{Ca}^{2+}$ in nutrient solution high in $\mathrm{Na}^{+}$ under alkaline conditions. Increased $\mathrm{Ca}$ uptake can result as a consequence of Si-mediated alleviation of primary stress, due to restored plasma membrane integrity and increased activity of $\mathrm{H}^{+}$-ATPase (Liang, 1999; Kaya et al., 2006). Experimental evidence of a direct role of $\mathrm{Si}$ in Ca-deficient plants is still lacking. Very recently da Silva et al. (2021) demonstrated Si-mediated alleviation of $\mathrm{Ca}$ deficiency in cabbage (Brassica oleracea var. capitata) grown in water culture which revealed an interesting $\mathrm{Ca}-\mathrm{Si}$ interaction pattern. In Ca-sufficient cabbage, $\mathrm{Si}$ addition decreased $\mathrm{Ca}$ accumulation in aerial parts but increased it in roots whereas in $\mathrm{Ca}$-deficient cabbage, $\mathrm{Si}$ addition increased $\mathrm{Ca}$ accumulation in aerial parts but was without effect on root accumulation.

\section{Magnesium and Sulfur}

According to the limited available literature on interactions of $\mathrm{Si}$ with magnesium $(\mathrm{Mg})$, the effect of $\mathrm{Si}$ appears to depend on plant species and environmental circumstances. Greger et al. (2018) reported that the addition of Si increased Mg uptake and accumulation in the shoots of several species grown in solution culture with optimal nutrient supply. Other studies likewise reported Si-mediated $\mathrm{Mg}$ accumulation in plants exposed to stress, as for instance under ammonium excesses in broccoli and cauliflower (Barreto et al., 2017) and in P-deficient tomato (Zhang et al., 2019). Investigating Si supply to drought stressed cultivars of sunflower (Helianthus annuus) in a pot experiment, 8 of the 12 cultivars accumulated higher amounts of $\mathrm{Mg}$ in their shoots when supplied with Si compared to drought stress alone (Gunes et al., 2009). The effect on uptake per se, however, was not so clear-cut when yield data were taken into account (Gunes et al., 2008). To date, the effect of Si on the expression of $\mathrm{Mg}$ transporters has not been demonstrated. Indeed, only two studies have investigated the effect of $\mathrm{Si}$ on Mg-deficient plants. Buchelt et al. (2020) reported Simediated alleviation of $\mathrm{Mg}$ stress in forage crops, but attributed it to increased $\mathrm{Mg}$ use efficiency, rather than increased $\mathrm{Mg}$ uptake. The study by Hosseini et al. (2019) showed that Si supply had no influence on the uptake and/or translocation of $\mathrm{Mg}$ in maize plants. The authors proposed the growth of the deficient plants was sustained indirectly by the beneficial role of $\mathrm{Si}$ in significantly increasing the levels of chlorophyll and by regulating sugar metabolism and hormonal balance (Hosseini et al., 2019).

Work on interactions of $\mathrm{Si}$ with sulfur $(\mathrm{S})$ is at a preliminary stage. Early results indicate that uptake and accumulation of $S$ was unaffected by Si supply in forages crops (Panicum maximum and Brachiaria ruziziensis $\times$ Brachiaria brizantha) (Buchelt et al., 2020) while Si supply even decreased shoot accumulation of $\mathrm{S}$ in barley and rice exposed to $\mathrm{S}$ deficiency (Maillard et al., 2018; Réthoré et al., 2020). Molecular analysis also showed that the addition of $\mathrm{Si}$ tended to decrease transcript levels of S transporters (OsSULTR) in rice (Réthoré et al., 2020; see Table 1).

\section{INTERACTIONS OF SILICON WITH MICRONUTRIENTS}

\section{Iron}

The effect of Si on iron (Fe) nutrition was clearly demonstrated in different plant species grown in optimal, low or high $\mathrm{Fe}$ conditions (e.g., Gonzalo et al., 2013; Pavlovic et al., 2013; Chalmardi et al., 2014; dos Santos et al., 2019; Nikolic et al., 2019; Becker et al., 2020; Hernández-Apaolaza et al., 2020). In general, the results suggest that $\mathrm{Si}$ addition strongly affects Fe availability in the rhizosphere and the root apoplast (directly or indirectly), as well as the expression of genes involved in Fe transport at both root and leaf level, thus influencing Fe uptake, translocation and distribution within different plant organs and tissues.

The alleviating effect of Si on Fe deficiency has been shown in both Strategy 1 (dicots and non-graminaceous monocots with reduction-based Fe uptake; Gonzalo et al., 2013; Pavlovic et al., 2013; Bityutskii et al., 2014) and Strategy 2 (graminaceous monocots that exhibit chelation-based Fe uptake; Nikolic et al., 2019; Teixeira et al., 2020) plant species. Moreover, the Siameliorative effect on Fe deficiency was found to be speciesspecific and pH-dependent (Gonzalo et al., 2013; Bityutskii et al., 2018). Supplying Si to cucumber roots, extended the binding pool for Fe in the root apoplast, and further promoted apoplastic Femobilization by increasing the expression of key genes involved in the biosynthesis of organic acids acting as strong Fe chelators, i.e., ICD for citric acid and $M D H$ for malic acid (Pavlovic et al., 2013). Silicon supply also induces up-regulation of the Strategy 1 genes (FRO encoding transmembrane protein involved in $\mathrm{Fe}^{3+}$ reduction and IRT1 encoding $\mathrm{Fe}^{2+}$ transporter; see Table 1) in both common corn salad (Valerianella locusta) (Gottardi et al., 2012) and cucumber (Pavlovic et al., 2013). Enhancement of Fe distribution toward apical shoot parts, along with the tissue accumulation of Fe-mobilizing compounds such as citrate (in leaves and roots) and catechin (in roots) appears to be the major alleviating effect of Si (Bityutskii et al., 2014). Furthermore, Stevic et al. (2016) showed that addition of $\mathrm{Si}(\mathrm{OH})_{4}$ to Fe-deprived cucumber plants can increase Fe bioavailability through formation of an Fe-Si complex and maintaining the redox potential in both root apoplastic and xylem fluids, thus facilitating root-to-shoot Fe translocation via the xylem. At the leaf level, Si stimulated the expression of both CsNAS1, and subsequent accumulation of nicotianamine (NA), and CsYSL1 the encoding transporter involved in phloem loading/unloading of the Fe-NA complex, thereby enhancing remobilization and retranslocation of $\mathrm{Fe}$ from older (sink) to younger (source) leaves in Fe-deficient cucumber plants (Pavlovic et al., 2016; Table 1). Moreover, Nikolic et al. (2019) recently reported that Si mitigates Fe deficiency in barley (Strategy 2 species) by enhancing the expression of genes involved in Fe uptake and transport in roots, such as HvNAS1 and HvDMAS1 [responsible for biosynthesis of phytosiderophores (PS)], HvTOM1 (encoding efflux transporter of PS), and HvYS1 (encoding influx transporter 
for Fe-PS), thereby increasing Fe uptake. Additionally, Si supply increased the transcript abundance of HvYS1 and HvDMAS1 in leaves, responsible for metal redistribution between root and shoot. Interestingly, the effect of $\mathrm{Si}$ on regulation of both Strategy 1 and Strategy 2 genes transcripts showed strong timedependency (see Table 1).

The role of $\mathrm{Si}$ in Fe-toxicity, extensively studied in rice, demonstrated that $\mathrm{Si}$ alleviates $\mathrm{Fe}$-toxicity through precipitation of $\mathrm{Fe}$ in the growth media or formation of $\mathrm{Fe}$ plaque at the root surface (Fu et al., 2012). It has been suggested that $\mathrm{Si}$ supply decreases $\mathrm{Fe}$ uptake and translocation to aerial parts in rice, thus lowering $\mathrm{Fe}$ concentrations in both leaf and root tissues of plants exposed to Fe excess (Chalmardi et al., 2014; Dufey et al., 2014; dos Santos et al., 2019). Several recent studies on rice (Carrasco-Gil et al., 2018.; Becker et al., 2020) and cucumber (Hernández-Apaolaza et al., 2020) have reported that the addition of Si to the growth media caused higher Fe plaque formation, thus decreasing $\mathrm{Fe}$ uptake and activating root $\mathrm{Fe}$ deficiency responses even at optimal Fe supply, supporting the hypothesis postulated by Coskun et al. (2019) that Si may cause an apoplastic obstruction.

\section{Zinc}

Several strands of evidence indicate interaction between Si and zinc $(\mathrm{Zn})$ in plants under both deficient and excess $\mathrm{Zn}$ conditions (e.g., Gu et al., 2012; Bityutskii et al., 2014). For instance, $\mathrm{Si}$ application prevented certain symptoms of $\mathrm{Zn}$-deficiency (necrotic spots) in cucumber plants, most probably due to its indirect effect by enhancing antioxidant defense capacity in plant tissues, rather than to its direct effect on mobility, uptake and tissue distribution of $\mathrm{Zn}$ (Bityutskii et al., 2014). In rice, Si supply increased shoot biomass and grain yield under low $\mathrm{Zn}$ conditions, which was associated with increased $\mathrm{Zn}$ concentration in the shoots (Mehrabanjoubani et al., 2015). Pascual et al. (2016) proposed that Si treatment enhanced $\mathrm{Zn}$ accumulation in the root apoplast as well as its movement to shoots when soybean plants were subjected to $\mathrm{Zn}$ deficiency, thus mitigating stress symptoms. However, the direct effects of $\mathrm{Si}$ on $\mathrm{Zn}$-transporters by maintaining optimum $\mathrm{Zn}$-concentration within plants have not as yet been verified.

The beneficial effects of $\mathrm{Si}$ have been observed under $\mathrm{Zn}$ toxicity stress in several crop species such as rice (Song et al., 2011, 2014; Gu et al., 2012; Huang and Ma, 2020), cotton (Gossypium hirsutum) (Anwaar et al., 2015) and maize (Vieira da Cunha et al., 2008; Kaya et al., 2009). However, in some studies Si application did not alleviate Zn-toxicity as for instance in young seedlings of sorghum (Masarovič et al., 2012) and maize (Bokor et al., 2013). In spring sandwort (Minuartia verna), a dicotyledonous $\mathrm{Si}$-accumulator, co-precipitated $\mathrm{Zn}$-silicates were detected in the leaf epidermal cell wall which was associated with Zn tolerance (Neumann et al., 1997). Gu et al. (2012) also observed $\mathrm{Zn}$ and Si co-localized in cell walls in stems, sheaths and leaves of rice seedlings after $\mathrm{Si}$ addition. In addition to in planta $\mathrm{Zn}$-Si colocalization, many studies reported that $\mathrm{Si}$ reduces bioavailability of $\mathrm{Zn}$ in soil by allocating this metal into more stable fractions such as organic matter and crystalline Feoxides (Vieira da Cunha et al., 2008). Fan et al. (2016) showed that $\mathrm{Si}$ affects the exudation of various organic acids (e.g., oxalic, acetic, tartaric, maleic and fumaric acids), from rice roots which may be involved in amelioration of $\mathrm{Zn}$ toxicity possibly by immobilization/co-precipitation in the soil solution.

Song et al. (2011) demonstrated that Si supply significantly decreased $\mathrm{Zn}$ concentration in shoots of two rice cultivars differing in tolerance to $\mathrm{Zn}$ excess, indicating lower root-to-shoot translocation of $\mathrm{Zn}$, despite increased root $\mathrm{Zn}$ concentrations. However, the authors suggest that Si-mediated alleviation of $\mathrm{Zn}$ toxicity is mainly attributed to increased Si-mediated antioxidant defense capacity and membrane integrity (Song et al., 2011). Furthermore, Huang and Ma (2020) investigated the interaction between $\mathrm{Si}$ and $\mathrm{Zn}$ in rice at different levels of $\mathrm{Zn}$ supply using WT cv. Oochikara and its lsi1 mutant defective in Si uptake. In contrast to the previous study (Song et al., 2011), a short-term uptake experiment of Huang and Ma (2020) demonstrated that Si decreased root uptake of the stable isotope ${ }^{67} \mathrm{Zn}$, but did not affect the root-to-shoot translocation of ${ }^{67} \mathrm{Zn}$ in the WT. The results of this study suggest that $\mathrm{Si}$ accumulated in the shoot suppresses $\mathrm{Zn}$ through down-regulation of OsZIP1, the encoding transporter involved in $\mathrm{Zn}$ uptake (see Table 1), rather than by directly alleviating symptoms of $\mathrm{Zn}$ toxicity (e.g., oxidative tissue damage) as observed in the study of Song et al. (2011).

Greger et al. (2018) also reported that Si decreased $\mathrm{Zn}$ net accumulation in several plant species [(i.e., maize, lettuce (Lactuca sativa), wheat, carrot (Daucus carota) and pea (Pisum sativum)] even with adequate $\mathrm{Zn}$ supply, although the root $\mathrm{Zn}$ concentration increased. The authors therefore conclude that the binding of $\mathrm{Zn}$ to $\mathrm{Si}$ in the roots prevents $\mathrm{Zn}$ translocation to the shoot. But this poses another question which urgently needs an answer. Does Si application under low $\mathrm{Zn}$ conditions induce $\mathrm{Zn}$ deficiency?

\section{Manganese}

Greger et al. (2018) showed that Si applied to soil increases manganese $(\mathrm{Mn})$ availability and promotes $\mathrm{Mn}$ uptake and translocation to shoots in various plant species grown under conditions of adequate Mn supply. Only two studies, however, reported Si-mediated alleviation of Mn-deficiency (Bityutskii et al., 2014; de Oliveira et al., 2019). In cucumber, Si addition partly alleviated Mn-deficiency, possibly by indirectly reducing oxidative stress without increasing $\mathrm{Mn}$ transport and tissue accumulation (Bityutskii et al., 2014). Similarly, de Oliveira et al. (2019) showed that Si mitigates the effects of oxidative stress induced by Mn deficiency in sorghum plants by regulating the physiology and activity of antioxidative enzymes. Accumulation of $\mathrm{Mn}$ as a consequence of $\mathrm{Si}$ application was not observed. Considered together, these findings suggest that for plants inadequately supplied with Mn, Si supply plays an indirect role of improving antioxidant performance in mitigating the symptoms of Mn deficiency induced by ROS formation, rather than a direct one of increasing uptake and/or remobilization of Mn.

Interactions between $\mathrm{Si}$ and $\mathrm{Mn}$ in rice plants subjected to high Mn have been mainly attributed to decreased Mn accumulation in shoots (Horiguchi, 1988; Li et al., 2012). Decrease in Mn uptake can be explained by enhanced Mn oxidizing capacity of the rice roots, resulting in oxidation of plant-available $\mathrm{Mn}^{2+}$ on the root 
surfaces (Okuda and Takahashi, 1962). Che et al. (2016) showed Si-decreased Mn accumulation in rice shoots by decreasing rootto-shoot translocation of $\mathrm{Mn}, \mathrm{Mn}$-Si complex formation in root cells, and down-regulation of Mn-transporter gene OsNramp5. Enhanced Mn-tolerance was stimulated by Si in both Mn-tolerant and Mn-sensitive rice genotypes (Li et al., 2012). In the sensitive genotypes $\mathrm{Mn}$ increased in roots but not in shoots, whereas in the tolerant cultivars $\mathrm{Mn}$ was lower in both roots and shoots ( $\mathrm{Li}$ et al., 2012). Indirectly, Si also enhanced Mn tolerance in rice by increasing synthesis of chlorophyll and ATP molecules and by stabilizing the structure of photosystem I (PSI) impaired by toxic $\mathrm{Mn}$, which resulted in increased $\mathrm{CO}_{2}$ assimilation (Li et al., 2015). The exact mechanisms controlling Si-increased Mn tolerance in rice still remain unknown.

By contrast to rice, in many other plant species Si-induced Mn tolerance was attributed to altering Mn distribution within the plant, rather than by reducing Mn uptake (e.g., DragisicMaksimovic et al., 2012; Li et al., 2012; Che et al., 2016). For example, Si increased Mn-tolerance in pumpkin by localized accumulation of $\mathrm{Mn}$ in a metabolically inactive form at the base of trichomes of the leaf surface (Iwasaki and Matsumura, 1999). Conversely Si application resulted in homogenous distribution of $\mathrm{Mn}$ in the leaves of barley and common bean (Williams and Vlamis, 1957; Horiguchi and Morita, 1987). In maize, Si alleviates $\mathrm{Mn}$ toxicity by increasing the thickness of the epidermal layers, suggesting that Mn storage in nonphotosynthetic tissue could be a Mn tolerance mechanism in this C4 crop (Doncheva et al., 2009). Iwasaki et al. (2002) also showed that total shoot Mn concentration was unaffected by Si supply. In cucumber, Si increased binding capacity of the cell wall to $\mathrm{Mn}$, thereby lowering $\mathrm{Mn}$ concentration within the symplasm (Rogalla and Römheld, 2002a) and decreasing the free leaf apoplasmic $\mathrm{Mn}^{2+}$ as a catalyst for the Fenton reaction (Dragisic-Maksimovic et al., 2012). In support of these findings, Blamey et al. (2018) demonstrated that Si decreases Mn toxicity symptoms in cowpea, soybean and sunflower through increased Mn localization in leaf tissues by directly increasing apoplastic sequestration of $\mathrm{Mn}$, in a nontoxic form, thereby decreasing apoplastic $\mathrm{Mn}^{2+}$ and excess $\mathrm{Mn}$ accumulation in the cytoplasm or apoplast. High Mn concentrations may have inhibited photosynthesis through several mechanisms, including suppressing chlorophyll and ATP synthesis, decreasing lightharvesting processes, impairing (PSI) stability and structure, and slowing activity of phosphoribulokinase.

\section{Copper}

So far, interactions of $\mathrm{Si}$ with copper $(\mathrm{Cu})$ have been studied in the context of $\mathrm{Cu}$ excess. Addition of $\mathrm{Si}$ relieved symptoms of $\mathrm{Cu}$-toxicity such as chlorosis and reduction of the shoot and root biomass in wheat (Nowakowski and Nowakowska, 1997) and Arabidopsis thaliana (Li J. et al., 2008; Khandekar and Leisner, 2011). In general, Si-mediated alleviation of $\mathrm{Cu}$ toxicity is mostly attributed to the immobilization of toxic $\mathrm{Cu}$ ions by enhancement of the cell wall binding capacity and the synthesis of Cu-binding molecules, both in roots and shoots. Although Si decreased the expression levels of two $\mathrm{Cu}$ transporter genes, AtCOPT1 and AtHMA5 in Arabidopsis roots
(Table 1), it did not cause any changes in $\mathrm{Cu}$ status in leaves (Li J. et al., 2008). The authors explained that Si deposits formed in the cell walls increased Cu-binding sites and thus decreased impact of high $\mathrm{Cu}$ level in plant cells (Li J. et al., 2008). Furthermore, the expression of metallothioneins (MTs), the Cu-binding molecules, was maintained at high levels or is even increased in Si-treated plants suggesting that Si may also contribute to regulation of intracellular homeostasis of $\mathrm{Cu}$, besides extending the additional cell wall binding sites for $\mathrm{Cu}$ (Khandekar and Leisner, 2011). However, Keller et al. (2015) found that $\mathrm{Si}$ induces $\mathrm{Cu}$ accumulation in the root epidermal cells, thus limiting root-to-shoot $\mathrm{Cu}$ translocation wheat (Triticum turgidum) seedlings. The author proposed a three-step mechanism: (1) increased $\mathrm{Cu}$ adsorption onto the outer thin layer root surface and immobilization in the vicinity of root epidermis; (2) increased $\mathrm{Cu}$ complexation by both inorganic and organic anions such as aconitate; and (3) limitation of translocation through the thickened Si-loaded endodermis areas. In bamboo (Phyllostachys fastuosa), Si also increased the concentration of S-ligands that chelate $\mathrm{Cu}^{+}$into a less toxic form (Collin et al., 2014). Mateos-Naranjo et al. (2015) found that Si plays an important role in the $\mathrm{Cu}$-tolerance of Spartina densiflora by reducing the excessive $\mathrm{Cu}$ translocation from roots to leaves.

Carrasco-Gil et al. (2018) demonstrated that Si application causes higher Fe plaque formation on the root surface of rice which significantly increased $\mathrm{Cu}$ concentration, probably as a consequence of a $\mathrm{Fe} / \mathrm{Cu}$ antagonism. Silicon reduces $\mathrm{Cu}$ toxicity symptoms in Erica andevalensis by decreasing translocation of $\mathrm{Cu}$ from roots to shoots, and also by immobilizing or deactivating $\mathrm{Cu}$ in the Si phytoliths in leaves (Oliva et al., 2011). Recently, Bosnic et al. (2019a) provided evidence that binding of $\mathrm{Cu}$ to the $\mathrm{Cu}$-chelating proteins, such as $\mathrm{Zn} / \mathrm{Cu} \mathrm{SOD}$ in roots and plastocyanin in leaves, are important components of the $\mathrm{Si}$ alleviating mechanism in cucumber exposed to $\mathrm{Cu}$ excess. In cucumber, Si supply also enhanced the $\mathrm{Cu}$ binding capacity of the root cell wall, as well as the accumulation of $\mathrm{Cu}$-ligands such as organic acids (citrate and malate in the roots and aconitate in the leaves) and amino acids (nicotianamine and histidine) in leaves (Bosnic et al., 2019a,b). Flora et al. (2019) suggested that $\mathrm{Si}$-mediated alleviation of $\mathrm{Cu}$ toxicity in tobacco (Nicotiana tabacum) by decreasing root uptake of $\mathrm{Cu}$, also down-regulates expression of NtCOPT1 (Table 1), and elevates expression of genes involved in biosynthesis of ethylene. Similarly, Kim et al. (2014) suggested that a higher accumulation of Si in the roots of $\mathrm{Cu}$-stressed rice plants in turn reduced influx of $\mathrm{Cu}$ by down-regulation of metal transporter genes OsHMA2 and OsHMA3 (Table 1).

\section{Boron}

The beneficial effect of $\mathrm{Si}$ on boron (B) disorders (deficiency and excess) has been reported for both dicotyledonous and graminaceous species and several mechanisms have been proposed by which Si can alter B uptake and transport. Both elements show considerable chemical similarity as for example in the presence of weak undissociated acids in aqueous solution and affinity for binding to polyhydroxy compounds (Brown et al., 1999; Kinrade et al., 1999). Moreover, both elements are 
taken up as uncharged acids $\left(\mathrm{H}_{4} \mathrm{SiO}_{4}{ }^{0}\right.$, pKa of 9.8; $\mathrm{H}_{3} \mathrm{BO}_{3}{ }^{0}$, $\mathrm{pKa}$ of 9.2) either actively or passively depending on their external concentrations. Under certain environmental conditions it is therefore possible that $\mathrm{Si}$ complexes with $\mathrm{B}$ in soil solution thus reducing availability of $\mathrm{B}$ and its potential phytotoxic effect (Nozawa et al., 2018). Although ameliorative effect of Si via decreased B accumulation has been reported in numerous species, i.e., tomato (Kaya et al., 2011), grapevine rootstocks (Vitis sp.) (Soylemezoglu et al., 2009) and spinach (Spinacia oleracea) (Gunes et al., 2007), the mechanism of Si-mediated B uptake and/or transport still remains purely speculative. According to Rogalla and Römheld (2002b), application of Si to cucumber exposed to high B had no effect on total B concentration, but strongly affected B compartmentation within leaves; a higher B concentration was found in the cell wall fraction than in the press sap of leaves of Si-treated cucumber plants.

In barley, Akcay and Erkan (2016) showed that simultaneous application of $\mathrm{B}$ and $\mathrm{Si}$ increased the transcript level of the gene encoding the BOR2 efflux transporter (see Table 1), responsible for $\mathrm{B}$ detoxification in the apoplast. Interestingly, the authors reported a higher transcript response in the shoot compared to the root which could explain the effective prevention of $\mathrm{B}$ accumulation and increased tolerance to high B (Miwa and Fujiwara, 2010). Accordingly, Akcay and Erkan (2016) reported the existence of a certain degree of competition within the $\mathrm{B}$ transport system favoring $\mathrm{Si}$ uptake, which was also the mechanism proposed for oilseed rape grown in excessive B (Liang and Shen, 1994). Indeed, in both barley and rice, B can be transported through the multifunctional HvNIP2;1 transporter (homolog of OsLsi1) which has been demonstrated in oocyte experiments (Schnurbusch et al., 2010; Mitani-Ueno et al., 2011). However, in barley genotypes differing in susceptibility to B toxicity, no competitive interaction was found in the uptake of Si and B (Nable et al., 1990).

\section{Chlorine and Nickel}

In saline soils, high concentrations of both sodium $(\mathrm{Na})$ and chlorine $(\mathrm{Cl})$ are equally phytotoxic. Most studies regarding the beneficial effect of $\mathrm{Si}$ under saline conditions have dealt with uptake, exclusion and compartmentation of $\mathrm{Na}$. It is for this reason that the effect of $\mathrm{Si}$ on $\mathrm{Cl}$ transport and accumulation under saline condition is much less well understood compared to $\mathrm{Na}$ (see "Sodium" subsection, below). In a study using three rice cultivars differing in salt tolerance, Shi et al. (2013) demonstrated that $\mathrm{Si}$ improved growth of all three cultivars and markedly decreased shoot but not root $\mathrm{Cl}^{-}$concentration. Moreover, $\mathrm{Si}$ supply increased transpiration rate, net photosynthetic rate, and stomatal conductance in plants exposed to salinity. The authors suggest, however, that $\mathrm{Si}$-mediated alleviation of $\mathrm{Cl}$ toxicity was mainly attributed to the reduction in root-to-shoot transport (Shi et al., 2013). In addition, some authors suggest that $\mathrm{Cl}^{-}$ recirculation from shoot to root via the phloem could offer an efficient mechanism in controlling $\mathrm{Cl}^{-}$accumulation in the plant shoot (White and Broadley, 2001). Liang and Ding (2002) reported lower $\mathrm{Cl}^{-}$accumulation in the epidermal, cortical and stellar cells of barley roots subjected to salt stress. Moreover, Si markedly decreased $\mathrm{Cl}$ concentration in various plant organs, such as shoots of tomato and spinach (Gunes et al., 2007), root of grapevine (Soylemezoglu et al., 2009), and root, stem, and leaves of aloe (Xu et al., 2015). However, the mechanism by which Si affects $\mathrm{Cl}$ transport, distribution and its accumulation in plant tissues remains to be elucidated.

It appears that only two studies have reported Si-mediated regulation of $\mathrm{Ni}$ uptake and accumulation in plants. It has been shown that $\mathrm{Si}$ addition decreased $\mathrm{Ni}$ concentrations in both roots and leaves of mustard (Brassica juncea) and cotton plants, thus alleviating the inhibitory effect of $\mathrm{Ni}$ stress on biomass production (Khaliq et al., 2016; Abd_Allah et al., 2019). The reason for reduced $\mathrm{Ni}$ uptake, however, may possibly be that of decreased soil $\mathrm{Ni}$ availability due to the increase in $\mathrm{pH}$ of soil fertilized with sodium metasilicate, rather than a Si-alleviating effect per se (Weng et al., 2003).

\section{INTERACTIONS OF SILICON WITH BENEFICIAL ELEMENTS}

\section{Aluminum}

Numerous studies, have shown that Si supply affects aluminum (Al) uptake, and subsequently plant tolerance to Al-toxicity, by either external (ex planta) and/or internal (in planta) mechanisms (see Hodson and Evans, 2020 and reference therein). Early investigations showed that the ameliorative effect of Si on Al toxicity could mainly be attributed to increased $\mathrm{pH}$ of the rhizosphere. Likewise in a hydroponic study with sorghum, Li et al. (1996) reported that Si-induced alleviation of Al toxicity was due to increase in $\mathrm{pH}$ and not to the direct effects of $\mathrm{Si}$ on $\mathrm{Al}$ in nutrient solution. From chemical studies on Al-Si interaction in solution it was also known that $\mathrm{pH}$ influenced the formation of sub-colloidal inert hydroxyaluminosilicate species (HAS) (Exley and Birchall, 1992, 1993). However, the potential impact of HAS on plant growth was not appreciated until Baylis et al. (1994) reported that at low $\mathrm{pH}$, a higher concentration $\mathrm{Si}$ was required to ameliorate Al toxicity by soybean; the authors postulated that basis for this higher demand for $\mathrm{Si}$ was the higher affinity of $\mathrm{Si}$ for $\mathrm{Al}$ in HAS formation at low $\mathrm{pH}$ (see Hodson and Evans, 2020). The beneficial effect of silicic acid was also confirmed in later studies on Al-Si interaction in maize (Ma et al., 1997). Interaction between $\mathrm{Al}$ and $\mathrm{Si}$ in the root apoplast is considered as a complex process governed by a range of interacting factors, such as apoplastic $\mathrm{pH}$ and concentrations of $\mathrm{Al}$ and $\mathrm{Si}$. Accordingly, Rowatt and Williams (1996) suggested that Si added to maize, buffered $\mathrm{H}^{+}$in the root apoplast which increased $\mathrm{pH}$ at the root surface, and thereby induced HAS formation. Similarly, Cocker et al. (1998) proposed the Si-induced formation of nontoxic HAS in the root apoplast of wheat as a more likely mechanism for controlling $\mathrm{Al}$ availability.

In addition to HAS formation, Corrales et al. (1997) suggested that decreased $\mathrm{Al}$ uptake can be due to enhanced root exudates that precipitate $\mathrm{Al}$. In this study, maize plants pre-treated with Si showed more hematoxylin stainable precipitates at the root surface compared to the -Si control. Colocalization of Si and $\mathrm{Al}$ was shown in the epidermal cells of sorghum roots (Hodson 
and Sangster, 1993) and in epidermal and hypodermal cells of wheat roots (Cocker et al., 1997). These authors hypothesized that colocalization of $\mathrm{Si}$ and $\mathrm{Al}$ may, to some extent, slow down $\mathrm{Al}$ transport from entering the inner root cortex. Recently, Kopittke et al. (2017) confirmed this hypothesis by clearly demonstrating colocalization of $\mathrm{Al}$ and $\mathrm{Si}$ in both mucigel and outer apoplast of the root apex of sorghum. Besides grasses, $\mathrm{Si}$ and $\mathrm{Al}$ codeposition in roots cortex cell walls has also been confirmed in woody species such Norway spruce (Picea abies L.) (Hodson and Wilkins, 1991; Prabagar et al., 2011). Likewise, in a study on Faramea marginata (Rubiaceae), considered as an $\mathrm{Al}$ accumulator, Britez et al. (2002) provided first evidence for Al-Si complexation, in plant shoot tissue. Since most species considered as $\mathrm{Al}$ accumulators use organic ligands (Hodson and Evans, 2020) for Al complexation, this work was first to show the complexation role of inorganic ligands. Similarly, in a study conducted on another member of Rubiaceae (Rudgea viburnoides), Malta et al. (2016) reported $\mathrm{Al}$ and $\mathrm{Si}$ co-localization mostly in the epidermis of roots, stems, and leaves.

Moreover, an interesting study by Feng et al. (2019) involving the root border cells of pea, showed that these cells were coated with extracellular silica layers, and therefore were able to adsorb $\mathrm{Al}$ on their surfaces preventing $\mathrm{Al}$ transport into the cells. Very recently, Xiao et al. (2021) reported involvement of Si in decreasing $\mathrm{Al}$ accumulation (i.e., non exchangeable $\mathrm{Al}$ fraction) in the cell wall of rice root apex by decreasing hemicellulose content, which is a main binding site for $\mathrm{Al}$ in the cell wall without affecting its cation exchange capacity.

\section{Sodium}

Extensive studies have shown that precipitated amorphous $\mathrm{Si}$ deposits can fortify the root apoplast and cell wall surrounding the vasculature (Gong et al., 2006). Si can therefore act as a mechanical barrier for root-to-shoot translocation of $\mathrm{Na}^{+}$via the apoplastic bypass route (Yeo et al., 1999), thus preventing accumulation of $\mathrm{Na}^{+}$in the shoot. However, bypass flow of $\mathrm{Na}^{+}$ in response to $\mathrm{Si}$ in rice has been shown to be cultivar dependent (Yeo et al., 1999; Flam-Shepherd et al., 2018). Very recently, Yan et al. (2021a) investigated the role of $\mathrm{Si}$ in bypass flow and root-to-shoot translocation of $\mathrm{Na}^{+}$in rice using lsil and lsi2 mutants defective in OsLsi1 and OsLsi2, respectively, and their wild types (WTs). Under salt stress, Si promoted plant growth and decreased root-to-shoot $\mathrm{Na}^{+}$translocation in WTs but not in mutants. The authors concluded that $\mathrm{Si}$-induced $\mathrm{Na}^{+}$bypass flow is a spatially dependent process which occurs mainly in the root endodermis. Besides acting directly as the apoplastic bypass route blocker, Si supply can also enhance lignification and suberization of the Casparian band (Fleck et al., 2015), by altering the expressions of genes related to phenol biosynthesis (Hinrichs et al., 2017), thus further protecting plants against uncontrolled $\mathrm{Na}^{+}$influx. Although evidence of tissue $\mathrm{Na}^{+}$complexation by $\mathrm{Si}$ is lacking, $\mathrm{Si}$ co-precipitation with $\mathrm{Na}^{+}$in the extracellular matrix was reported for wheat (Saqib et al., 2008). Bosnic et al. (2019c) demonstrated that $\mathrm{Si}$ supply increases binding capacity of cell walls of maize roots for $\mathrm{Na}^{+}$, thereby decreasing free $\mathrm{Na}^{+}$for transport through the plasma membrane. Considering that influx of $\mathrm{Na}^{+}$is mediated by various transporters some of which are sensitive to $\mathrm{Ca}^{2+}$ (Davenport and Tester, 2000; Demidchik and Tester, 2002), interaction of Si and Ca in growing media can lead to increased Na accumulation in roots (Dishon et al., 2011; Bosnic et al., 2019c).

Bosnic et al. (2018) demonstrated that Si supply to moderately $\mathrm{NaCl}$-stressed maize plants reduced $\mathrm{Na}$ concentration in the root symplast by up-regulating the expression of SOS1 (responsible for $\mathrm{Na}^{+}$efflux) and down-regulating the expression of HKT1 (responsible for $\mathrm{Na}^{+}$influx). These authors also demonstrated higher sequestration of $\mathrm{Na}^{+}$in the leaf vacuoles and concomitantly lower $\mathrm{Na}^{+}$concentrations in chloroplasts. This effect can be partially attributed to Si-mediated increase of both $\mathrm{H}^{+}$-ATPase and $\mathrm{H}^{+}$-PPase activities (Liang, 1999; Liang et al., 2005; Xu et al., 2015). However, a direct link between enzyme activities and the potential to generate a motive force for $\mathrm{H}^{+} / \mathrm{Na}^{+}$antiport for both plasma membrane and tonoplast still remains speculative.

Flam-Shepherd et al. (2018) tested the effects of Si in mediating ${ }^{24} \mathrm{Na}^{+}$membrane flux regulation in two hydroponically grown rice cultivars, one salt-sensitive (IR29) and the other salt-tolerant (Pokkali). Si had no effect on $\mathrm{Na}^{+}$influx or efflux or on $\mathrm{Na}^{+}$stimulated plasma membrane depolarization. However, it increased growth and lowered $\mathrm{Na}$ in shoots of both cultivars. In the salt sensitive cultivar IR29, Si lowered shoot $\mathrm{Na}$ by a large reduction in bypass flow whereas in cv. Pokkali where bypass flow was small, the lower $\mathrm{Na}$ resulted from growth dilution. The authors suggest that additionally other $\mathrm{Si}$ triggered processes are likely to underlie the improved growth of the two cultivars including changes in gene expression (Debona et al., 2017). The study also casts doubt on possible influence of $\mathrm{Si}$ on $\mathrm{Na}^{+}$transport across cell membranes into and out of roots.

\section{Selenium}

Selenium (Se) is an essential nutrient in the human diet and supplied to nearly half the world's population by the staple rice crop, a Si accumulator, which is however low in Se (Zhou et al., 2020). The interaction between Se and Si is thus of high importance. Two main plant-available Se inorganic forms viz. selenite and selenate are readily taken up by plant roots via both active and passive transport systems (Li H.-F. et al., 2008; Lazard et al., 2010). In rice, selenite, the main bioavailable Se form in paddy soils, uses the same root influx transporter (OsNIP2;1, known as OsLSi) as silicic acid (Zhao et al., 2010). These authors showed a significant decrease in the selenite concentration in both xylem sap and shoots in lsi1 rice mutant, but not in $l$ si2 mutant defective in Lsi2 efflux transporter (Zhao et al., 2010). Furthermore, they hypothesized that in the lsil mutant the absence of an antagonistic effect from silicic acid could be due to specific metabolic processes of Se in root cells following uptake with such Se-organo-complexes being loaded into the xylem via efflux transporters other than Lsi2.

In tomato, addition of a high $\mathrm{Si}$ dose $(1 \mathrm{mM})$ significantly decreased root concentration of Se at $\mathrm{pH} 3$, but had no effect at higher (up to 8) pH (Wang et al., 2019). Such pH-dependent disparity on Si effect could partially be explained by Si-influx 
transporter affinity for Se form available at the given $\mathrm{pH}$. Moreover, the presence of the fully operative Si influx transporter (SlLsi1), and the lack of functional Si efflux transporter (SILsi2; involved in xylem loading of Si) in tomato (Sun et al., 2020), could also explain the lower Se accumulation in the tomato roots as a consequence of $\mathrm{Si} / \mathrm{Se}$ uptake antagonism, as well as lack of Si effect on Se accumulation in the shoot reported by Wang et al. (2019).

\section{ESSENTIAL AND BENEFICIAL ELEMENT STATUS AFFECTS SILICON UPTAKE AND DISTRIBUTION}

To date, two different Si transporters, Lsi (channels) and Lsi2 (anion-type transporter) have been characterized in the roots of various plant species including rice, barley, maize, wheat, soybean, pumpkin, cucumber, tobacco, sorghum, tomato (for recent review see Mitani-Ueno and $\mathrm{Ma}, 2020$ ), and recently date palm (Phoenix dactylifera) (Bokor et al., 2019) and grapevine (Noronha et al., 2020) have been added to the list. All these species differ greatly in ability to accumulate $\mathrm{Si}$ in upper plant parts. Silicon in the form of $\mathrm{H}_{4} \mathrm{SiO}_{4}$ enters the roots via influx aquaporin channels belonging to the Nodulin 26like intrinsic proteins (NIPs) and is then, exported out of the endodermis as $\mathrm{H}_{4} \mathrm{SiO}_{3}{ }^{-}$via the efflux anion $\mathrm{H}^{+}$/antiporter Lsi2, and loaded into the xylem. However, the expression pattern, cell-type-specific expression, polar localization and functionality of these transporters differ among plant species. For instance, tomato which shows very low shoot accumulation of $\mathrm{Si}$, has the functional influx transporter SILsil for root uptake of Si, but not the functional efflux transporter SlLsi2 for its upward transport (Sun et al., 2020). Once loaded into the xylem, Si is moved upward to the shoot by the transpiration stream, and is finally unloaded from the xylem vessels via Lsi6 (Mandlik et al., 2020). Lsi6 is an influx channel homolog of Lsi1, which shows polar localization in the xylem parenchyma cells. As yet, Lsi6 has been characterized only in rice, barley and maize.

Whether nutrition imbalance (deficiency or excess) can influence root uptake, root-to-shoot transport and tissue distribution of $\mathrm{Si}$ is still unknown. Resolving this puzzle is additionally complicated due to a lack of overall understanding of the Si uptake/transport system in the whole plant. Factors affecting the regulation of the Si-transport systems are almost completely unknown. So far, it has been demonstrated that Si down-regulates influx and efflux Si transporters (OsLsil and OsLs2) in rice (Mitani-Ueno et al., 2016). By contrast, in maize and barley, only efflux transporters (Lsi2) are down-regulated by Si (Mitani et al., 2009), while influx transporters Lsi1 are unaffected (Chiba et al., 2009). According to available literature, environmental factors such as drought or herbivore attack can also modulate Si uptake (e.g., Reynolds et al., 2009; Yamaji and Ma, 2011).

Increasing evidence suggests that nutritional status can affect Si accumulation and distribution in plants (e.g., Kim et al., 2014; Bokor et al., 2015; Hosseini et al., 2017; Wu et al., 2017; Chaiwong et al., 2020; Minden et al., 2020; Xiao et al., 2021). However, only a few studies have investigated the effect of specific nutrient imbalances on the expression of Si transporters and could be additionally affected by the Si concentration in the shoot (Mitani-Ueno and Ma, 2020). It has been shown that limited supply of the macronutrients $(\mathrm{N}, \mathrm{P}, \mathrm{K})$ and the micronutrient $\mathrm{Fe}$, can induce $\mathrm{Si}$ accumulation in plant roots and/or shoots (Wu et al., 2017; Chaiwong et al., 2018, 2020; de Tombeur et al., 2020; Minden et al., 2020). Exudation of organic ligands (mainly PSs) by roots of Fe deficient barley plants can indirectly increase Si availability in the rhizosphere (Gattullo et al., 2016), as a consequence of nutrient (e.g.,

TABLE 2 | Evidence for expression of Si transporter genes affected by supply of essential and beneficial elements.

\begin{tabular}{|c|c|c|c|c|c|}
\hline Conditions & Plant species & Localization/direction/form/function & $\begin{array}{l}\text { Si transporter } \\
\text { genes }\end{array}$ & $\begin{array}{l}\text { Expression pattern affected } \\
\text { by element supply }\end{array}$ & References \\
\hline \multirow[t]{2}{*}{ Low N } & Rice & Root/influx/ $\mathrm{H}_{4} \mathrm{SiO}_{4} /$ uptake & OsLsi1 & Up-regulated & Wu et al., 2017 \\
\hline & & Root/efflux/ $\mathrm{H}_{4} \mathrm{SiO}_{3}-$ /xylem loading & OsLsi2 & Up-regulated & \\
\hline \multirow[t]{2}{*}{ High N } & Rice & Root/influx/ $\mathrm{H}_{4} \mathrm{SiO}_{4} /$ uptake & OsLsi1 & Down-regulated & Wu et al., 2017 \\
\hline & & Root/efflux// $\mathrm{H}_{4} \mathrm{SiO}_{3}-/$ xylem loading & OsLsi2 & Down-regulated & \\
\hline \multirow[t]{3}{*}{ Low K } & Barley & Root/influx/ $\mathrm{H}_{4} \mathrm{SiO}_{4} /$ uptake & HVLsi1 & Up-regulated & Hosseini et al., 2017 \\
\hline & & Root/efflux// $\mathrm{H}_{4} \mathrm{SiO}_{3}{ }^{-} /$xylem loading & HVLsi2 & Up-regulated & \\
\hline & & Leaf/influx $/ \mathrm{H}_{4} \mathrm{SiO}_{4} / x y l e m$ unloading & HVLsi6 & Up-regulated & \\
\hline Low Fe & Rice & Root/influx/ $\mathrm{H}_{4} \mathrm{SiO}_{4} /$ uptake & OsLsi1 & Up-regulated & Chaiwong et al., 2020 \\
\hline \multirow[t]{2}{*}{ High Cu } & Rice & Root/influx/ $\mathrm{H}_{4} \mathrm{SiO}_{4} /$ uptake & OsLsi1 & Up-regulated & Kim et al., 2014 \\
\hline & & Root/efflux// $\mathrm{H}_{4} \mathrm{SiO}_{3}-/$ xylem loading & OsLsi2 & Up-regulated & \\
\hline \multirow[t]{3}{*}{ High Zn } & Maize & Root/influx/ $\mathrm{H}_{4} \mathrm{SiO}_{4} /$ uptake & $Z m L s i 1$ & Down-regulated & Bokor et al., 2015 \\
\hline & & Root/efflux// $\mathrm{H}_{4} \mathrm{SiO}_{3}{ }^{-} /$xylem loading & ZmLsi2 & Down-regulated & \\
\hline & & Leaf/influx/ $/ \mathrm{H}_{4} \mathrm{SiO}_{4} /$ xylem unloading & ZmLsi6 & Up-regulated & \\
\hline \multirow[t]{4}{*}{ High Al } & Rice & Root/influx/ $\mathrm{H}_{4} \mathrm{SiO}_{4}$ /uptake & OsLsi1 & Up-regulated & Xiao et al., 2021 \\
\hline & & Root/efflux// $\mathrm{H}_{4} \mathrm{SiO}_{3}-/$ xylem loading & OsLsi2 & Up-regulated & \\
\hline & Ryegrass & Root/influx/ $\mathrm{H}_{4} \mathrm{SiO}_{4} /$ uptake & LpLsi1 & Up-regulated & Pontigo et al., 2017 \\
\hline & & Root/efflux// $\mathrm{H}_{4} \mathrm{SiO}_{3}-/$ xylem loading & LpLsi2 & Up-regulated & \\
\hline
\end{tabular}




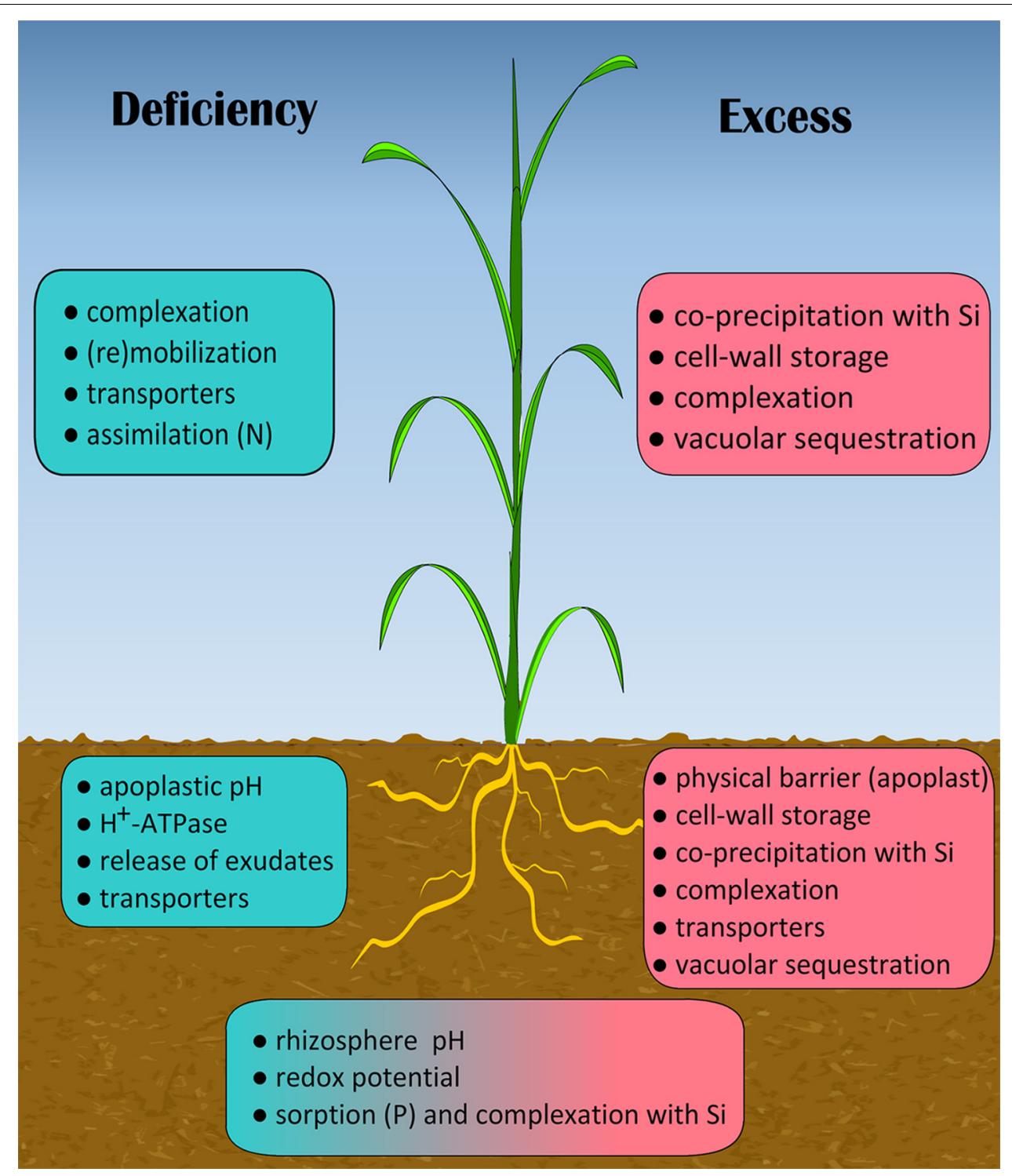

FIGURE 2 | Processes directly involved in rhizosphere mobilization, root uptake, root-to-shot transport and shoot utilization of essential (nutrients) and beneficial elements modulated by Si. Left (blue), nutrient deficiency; right (pink), excess of nutrients and beneficial elements; middle (blue/pink), nutrient deficiency or excess of nutrients and beneficial elements. General ameliorating effect of Si in stressed plants (e.g., increased tissue antioxidant capacity) may also improve overall plant performance thereby enhancing the above-mentioned processes.

Fe) mobilization from silicate minerals by liberation of silicic acid. In rice roots, low supply of both $\mathrm{N}$ and Fe led to upregulation of OsLsi1 (Wu et al., 2017; Chaiwong et al., 2020) and OsLsi2 (Wu et al., 2017). A similar effect was observed in K-deficient barley, where up-regulation of HvLsi1, HvLsi2 and HvLsi6 was responsible for accumulation of $\mathrm{Si}$ in the shoot (Hosseini et al., 2017). Moreover, $\mathrm{N}$ and $\mathrm{P}$ starvation influenced not only uptake but also distribution of Si; under P deficiency, the grass (Holcus lanatus) tended to accumulate $\mathrm{Si}$ in aboveground parts, whereas in $\mathrm{N}$ deficient plants of the same species, $\mathrm{Si}$ was accumulated in the roots (Minden et al., 2020). Under optimal growing conditions, however, Si was evenly distributed between shoot and roots. At a whole plant level, P-deficient plants take up more Si than those subjected to $\mathrm{N}$ deficiency (Minden et al., 2020).

On the other hand, exposure of plants to excessive supply of mineral nutrients also modulates expression of Si transporters, however, the effect (up- or down-regulation) seems to be dependent not only on plant species, but also on specific nutrient conditions. High $\mathrm{N}$ and $\mathrm{Zn}$ supply reduced transcript levels of Lsi1 and Lsi2 in rice and maize, thus limiting Si uptake and, consequently, decreasing Si content in roots and/or leaves (Bokor et al., 2015; Wu et al., 2017). Interestingly, in maize, ZmLsi6 was up-regulated (Bokor et al., 2015), potentially indicating Si re-translocation as a response to metal toxicity. In addition to the previously mentioned studies, several reports also showed 
that high $\mathrm{N}$ supply limits $\mathrm{Si}$ accumulation in various plant species such as wheat, rice and Brachypodium distachyon (e.g., Wu et al., 2017; Głazowska, 2018; Deus et al., 2020). The negative effect of high $\mathrm{N}$ supply on $\mathrm{Si}$ accumulation was confirmed in Brachypodium distachyon by comparing Si accumulation between WT and Bdls1-1, mutant defective in influx Si transporter Lsi1 (Głazowska, 2018). By contrast, high $\mathrm{Cu}$ or $\mathrm{Al}$ resulted in higher $\mathrm{Si}$ accumulation in tobacco, rice and ryegrass roots and/or leaves (Kim et al., 2014; Pontigo et al., 2017; Flora et al., 2019; Xiao et al., 2021), as a result of the increased expression of Lsi1 and Lsi2 (see Table 2).

\section{CONCLUSION AND PERSPECTIVES}

From this review, it is clear that interactions of Si with essential (nutrients) and beneficial mineral elements are largely plantspecific and also dependent on mineral status (deficiency or excess). These interactions firstly occur in the rhizosphere and in the root apoplast which include mobilization of nutrients from the rhizosphere by root exudates under low nutrient conditions and by buffering soil and cell wall availability under excess (Figure 2). Moreover, $\mathrm{Si}$ is able to control the availability of different elements in soils by competing for binding on soil particles depending on speciation of silicic acid (for review see Schaller et al., 2021). In the context of root uptake and transport (including remobilization) of nutrients, Si supply affects the expression of transporter genes differently for several mineral elements (Table 1), although the use of gene expression as a proxy for change in transport protein abundance or activity needs to be treated with caution (Coskun et al., 2019). On the other hand, nutrient status and excess of some beneficial elements may alter expression of Si transporter genes (Lsi1, Lsi2, Lsi6) thereby changing uptake and distribution of Si in plants (Table 2). The effectiveness of Si on overall plant performance depends on both $\mathrm{Si}$ and nutrient tissue concentrations, so that the existence of a feed-back loop between Si and nutrients is self-evident although the nature of this cross-linkage is unclear.

\section{REFERENCES}

Abd_Allah, E. F., Hashem, A., Alam, P., and Ahmad, P. (2019). Silicon alleviates nickel-induced oxidative stress by regulating antioxidant defense and glyoxalase systems in mustard plants. J. Plant Growth Regul. 38, 1260-1273. doi: 10.1007/ s00344-019-09931-y

Akcay, U. C., and Erkan, I. E. (2016). Silicon induced antioxidative responses and expression of BOR2 and two PIP family aquaporin genes in barley grown under boron toxicity. Front. Plant. Mol. Biol. Rep. 34:318-326. doi: 10.1007/s11105015-0923-5

Ali, N., Réthoré, E., Yvin, J.-C., and Hosseini, S. A. (2020). The regulatory role of silicon in mitigating plant nutritional stresses. Plants 9:1779. doi: 10.3390/ plants9121779

Anwaar, S. A., Ali, S. S., Ishaque, W., Farid, M., Farooq, M. A., Najeeb, U., et al. (2015). Silicon (Si) alleviates cotton (Gossypium hirsutum L.) from zinc ( $\mathrm{Zn}$ ) toxicity stress by limiting $\mathrm{Zn}$ uptake and oxidative damage. Environ. Sci. Pollut. Res. 22, 3441-3450. doi: 10.1007/s11356-014-3938-9

Barreto, F. R., Schiavon Júnior, A. A., Maggio, M. A., and de Mello Prado, R. (2017). Silicon alleviates ammonium toxicity in cauliflower and in broccoli. Sci. Hortic. 225, 743-750. doi: 10.1016/j.scienta.2017.08.014
The role of $\mathrm{Si}$ in modulating nutrient acquisition and utilization appears to be more complex (Figure 2), and thus the possibility of a signaling function of $\mathrm{Si}$ in transcriptional regulation of genes responsible for root acquisition and tissue retranslocation cannot be disregarded. Clearly, $\mathrm{Si}$ is involved in a variety of mechanisms in regulating nutrient deficiency and toxicity in different plant species. Therefore, a comprehensive understanding of the role of $\mathrm{Si}$ in regulation of uptake and transport systems for nutrients and other mineral elements (including beneficial elements) and vice versa is urgently needed. In particular, we are far from fully understanding the molecular mechanisms of Si-mediated nutrient transport which may explain the wide diversity among plant species.

In this respect, a deeper understanding of exactly how $\mathrm{Si}$ regulates transcription of transporter genes will be of benefit in improving crop productivity, yield quality and food safety. Also, detailed knowledge of the specific role of nutrients in mobilization from rhizosphere to uptake and transport of $\mathrm{Si}$ is essential for increasing plant resistance to both biotic and abiotic stresses. We hope that this review will also foster new research in the study of interactions between $\mathrm{Si}$ and nutrients of relevance to improving use efficiency of mineral fertilizers and pesticides in agricultural practice.

\section{AUTHOR CONTRIBUTIONS}

MN conceived this review. JP, LK, PB, and MN wrote the draft, and designed the figures and tables. $\mathrm{MN}$ and EAK reviewed the manuscript. All authors approved the final version.

\section{FUNDING}

This work was supported by the Serbian Ministry for Education, Science, and Technological Development (Contract No. 451-039/2021-14).

Barreto, R. F., de Mello Prado, R., Lúcio, J. C. B., López-Díaz, I., Carrera, E., and Carvalho, R. F. (2021). Ammonium toxicity alleviation by silicon is dependent on cytokinins in tomato cv. Micro-tom. J. Plant Growth Regul. doi: 10.1007/ s00344-021-10314-5

Baylis, A. D., Gragopoulou, C., Davidson, K. J., and Birchall, J. D. (1994). Effects of silicon on the toxicity of aluminium to soybean. Commun. Soil Sci. Plant Anal. 25, 537-546. doi: 10.1080/00103629409369061

Becker, M., Ngo, N. S., and Schenk, M. K. A. (2020). Silicon reduces the iron uptake in rice and induces iron homeostasis related genes. Sci. Rep. 10:5079. doi: 10.1038/s41598-020-61718-4

Bityutskii, N. P., Yakkonen, K. L., Petrova, A. I., Lukina, K. A., and Shavarda, A. L. (2018). Silicon ameliorates iron deficiency of cucumber in a pH-dependent manner. J. Plant Physiol. 231, 364-373. doi: 10.1016/j.jplph.2018.10.017

Bityutskii, N., Pavlovic, J., Yakkonen, K., Maksimovic, V., and Nikolic, M. (2014). Contrasting effect of silicon on iron, zinc and manganese status and accumulation of metal-mobilizing compounds in micronutrient-deficient cucumber. Plant Physiol. Biochem. 74, 205-211. doi: 10.1016/j.plaphy.2013.11. 015.9

Blamey, F. P. C., McKenna, B. A., Li, C., Cheng, M., Tang, C., Jiang, H., et al. (2018). Manganese distribution and speciation help to explain the effects of silicate 
and phosphate on manganese toxicity in four crop species. New Phytol. 217, 1146-1160. doi: 10.1111/nph.14878

Bokor, B., Bokorova, S., Ondos, S., Svubova, R., Lukacova, Z., Hyblova, M., et al. (2015). Ionome and expression level of Si transporter genes (Lsi1, Lsi2, and Lsi6) affected by $\mathrm{Zn}$ and $\mathrm{Si}$ interaction in maize. Environ. Sci. Pollut. Res. Int. 22, 6800-6811. doi: 10.1007/s11356-014-3876-6

Bokor, B., Soukup, M., Vaculík, M., Vd’ačný, P., Weidinger, M., Lichtscheidl, I., et al. (2019). Silicon uptake and localisation in date palm (Phoenix dactylifera) A unique association with sclerenchyma. Front. Plant Sci. 10:988. doi: 10.3389/ fpls.2019.00988

Bokor, B., Vaculík, M., Slovakova, L., Masarovič, D., and Lux, A. (2013). Silicon does not always mitigate zinc toxicity in maize. Acta Physiol. Plant 36, 733-743. doi: 10.1007/s11738-013-1451-2

Bosnic, D., Bosnic, P., Nikolic, D., Nikolic, M., and Samardzic, J. (2019a). Silicon and iron differently alleviate copper toxicity in cucumber leaves. Plants (Basel) 8:554. doi: 10.3390/plants8120554

Bosnic, D., Nikolic, D., Timotijevic, G., Pavlovic, J., Vaculík, M., Samardzic, J., et al. (2019b). Silicon alleviates copper (Cu) toxicity in cucumber by increased Cu-binding capacity. Plant Soil 441, 629-641. doi: 10.1007/s11104-01904151-5

Bosnic, P., Bosnic, D., Jasnic, J., and Nikolic, M. (2018). Silicon mediates sodium transport and partitioning in maize under moderate salt stress. Environ. Exp. Bot. 155, 681-687. doi: 10.1016/j.envexpbot.2018.08.018

Bosnic, P., Pavlicevic, M., Nikolic, N., and Nikolic, M. (2019c). High monosilicic acid supply rapidly increases $\mathrm{Na}$ accumulation in maize roots by decreasing external $\mathrm{Ca}^{2+}$ activity. J. Plant Nutr. Soil Sci. 182, 210-216. doi: 10.1002/jpln. 201800153

Brackhage, C., Schaller, J., Bäucker, E., and Dudel, E. G. (2013). Silicon availability affects the stoichiometry and content of calcium and micro nutrients in the leaves of common reed. Silicon 5, 199-204. doi: 10.1007/s12633-0139145-3

Britez, R. M., Watanabe, T., Jansen, S., Reissmann, C. B., and Osaki, M. (2002). The relationship between aluminium and silicon accumulation in leaves of faramea marginata (Rubiaceae). New Phytol. 156, 437-444. doi: 10.1046/j.1469-8137. 2002.00531.x

Brown, P. H., Bellaloui, N., Hu, H., and Dandekar, A. (1999). Transgenically enhanced sorbitol synthesis facilitates phloem boron transport and increases tolerance of tobacco to boron deficiency. Plant Physiol. 119, 17-20. doi: 10.1104/ pp.119.1.17

Buchelt, A. C., Teixeira, G. C. M., Oliveira, K. S., Rocha, A. M. S., de Mello Prado, R., and Caione, G. (2020). Silicon contribution via nutrient solution in forage plants to mitigate nitrogen, potassium, calcium, magnesium, and sulfur deficiency. J. Plant. Nutr. Soil Sci. 20, 1532-1548. doi: 10.1007/s42729-02000245-7

Campos, C. N. S., Silva Júnior, G. B., Prado, R. d. M., David, C. H. O. d., Souza Junior, J. P. d, and Teodoro, P. E. (2020). Silicon mitigates ammonium toxicity in plants. Agron. J. 112, 635-647. doi: 10.1002/agj2.20069

Carrasco-Gil, S., Rodriguez-Menendez, S., Fernandez, B., Pereiro, R., de la Fuente, V., and Hernandez-Apaolaza, L. (2018). Silicon induced Fe deficiency affects $\mathrm{Fe}, \mathrm{Mn}, \mathrm{Cu}$ and $\mathrm{Zn}$ distribution in rice (Oryza sativa $\mathrm{L}$.) growth in calcareous conditions. Plant Physiol. Biochem. 125, 153-163. doi: 10.1016/j.plaphy.2018.01. 033

Chaiwong, N., Bouain, N., Prom-U-Thai, C., and Rouached, H. (2020). Interplay between silicon and iron signaling pathways to regulate silicon transporter lsil expression in rice. Front. Plant Sci. 11:1065. doi: 10.3389/fpls.2020. 01065

Chaiwong, N., Prom, U. T. C., Bouain, N., Lacombe, B., and Rouached, H. (2018). Individual versus combinatorial effects of silicon, phosphate, and iron deficiency on the growth of lowland and upland rice varieties. Int. J. Mol. Sci. 19:899. doi: 10.3390/ijms19030899

Chalmardi, Z. K., Abdolzadeh, A., and Sadeghipour, H. R. (2014). Silicon nutrition potentiates the antioxidant metabolism of rice plants under iron toxicity. Acta Physiol. Plant. 36, 493-502. doi: 10.1007/s11738-013$1430-7$

Che, J., Yamaji, N., Shao, J. F., Ma, J. F., and Shen, R. F. (2016). Silicon decreases both uptake and root-to-shoot translocation of manganese in rice. J. Exp. Bot. 67, 1535-1544. doi: 10.1093/jxb/erv545
Chen, D., Cao, B., Qi, L., Yin, L., Wang, S., and Deng, X. (2016a). Silicon-moderated $\mathrm{K}$-deficiency-induced leaf chlorosis by decreasing putrescine accumulation in sorghum. Ann. Bot. 118, 305-315. doi: 10.1093/aob/mcw111

Chen, D., Cao, B., Wang, S., Liu, P., Deng, X., Yin, L., et al. (2016b). Silicon moderated the $\mathrm{K}$ deficiency by improving the plant-water status in sorghum. Sci Rep. 6:22882. doi: 10.1038/srep22882

Chiba, Y., Mitani, N., Yamaji, N., and Ma, J. F. (2009). HvLsi1 is a silicon influx transporter in barley. Plant J. 57, 810-818. doi: 10.1111/j.1365-313X.2008. 03728.x

Chiou, T. J., and Lin, S. I. (2011). Signaling network in sensing phosphate availability in plants. Annu. Rev. Plant Biol. 62, 185-206. doi: 10.1146/annurevarplant-042110- 103849

Cocker, K. M., Evans, D. E., and Hodson, M. J. (1998). The amelioration of aluminium toxicity by silicon in wheat (Triticum aestivum $\mathrm{L}$.): malate exudation as evidence for an in planta mechanism. Planta 204, 318-323. doi: 10.1007/ s004250050262

Cocker, K. M., Hodson, M. J., Evans, D. E., and Sangster, A. G. (1997). Interaction between silicon and aluminum in Triticum aestivum L. (cv. Celtic). Isr. J. Plant Sci. 45, 285-292. doi: 10.1080/07929978.1997.10676691

Collin, B., Doelsch, E., Keller, C., Cazevieille, P., Tella, M., Chaurand, P., et al. (2014). Evidence of sulfur-bound reduced copper in bamboo exposed to high silicon and copper concentrations. Environ. Pollut. 187, 22-30. doi: 10.1016/j. envpol.2013.12.024

Cooke, J., and Leishman, M. R. (2016). Consistent alleviation of abiotic stress with silicon addition: a meta-analysis. Funct. Ecol. 30, 1340-1357. doi: 10.1111/13652435.12713

Corrales, I., Poschenrieder, C., and Barceló, J. (1997). Influence of silicon pretreatment on aluminium toxicity in maize roots. Plant Soil 190, 203-209. doi: 10.1023/A:1004209828791

Coskun, D., Deshmukh, R., Sonah, H., Menzies, J. G., Reynolds, O., Ma, J. F., et al. (2019). The controversies of silicon's role in plant biology. New Phytol. 221, 67-85. doi: 10.1111/nph.15343

Cuong, T. X., Ullah, H., Datta, A., and Hanh, T. C. (2017). Effects of silicon-based fertilizer on growth, yield and nutrient uptake of rice in tropical zone of vietnam. Rice sci. 24, 283-290. doi: 10.1016/j.rsci.2017. 06.002

da Silva, D. L., de Mello Prado, R., Tenesaca, L. F. L., da Silva, J. L. F., and Mattiuz, B. H. (2021). Silicon attenuates calcium deficiency by increasing ascorbic acid content, growth and quality of cabbage leaves. Sci. Rep. 11:1770. doi: 10.1038/ s41598-020-80934-6

Davenport, R. J., and Tester, M. (2000). A weakly voltage-dependent, nonselective cation channel mediates toxic sodium influx in wheat. Plant Physiol. 122, 823-834. doi: 10.1104/pp.122.3.823

de Oliveira, R. L. L., de Mello Prado, R., Felisberto, G., Checchio, M. V., and Gratão, P. L. (2019). Silicon mitigates manganese deficiency stress by regulating the physiology and activity of antioxidant enzymes in sorghum plants. J. Soil Sci. Plant Nutr. 19, 524-534. doi: 10.1007/s42729-01900051-w

de Tombeur, F., Turner, B. L., Laliberté, E., Lambers, H., Mahy, G., Faucon, M.-P., et al. (2020). Plants sustain the terrestrial silicon cycle during ecosystem retrogression. Science 369, 1245-1248. doi: 10.1126/science.abc 0393

Debona, D., Rodrigues, F. A., and Datnoff, L. E. (2017). Silicon's role in abiotic and biotic plant stresses. Annu. Rev. Phytopathol. 55, 85-107. doi: 10.1146/annurevphyto-080516-035312

Demidchik, V., and Tester, M. (2002). Sodium fluxes through nonselective cation channels in the plasma membrane of protoplasts from Arabidopsis roots. Plant Physiol. 128, 379-387. doi: 10.1104/pp.010524

Detmann, K. C., Araujo, W. L., Martins, S. C., Sanglard, L. M., Reis, J. V., Detmann, E., et al. (2012). Silicon nutrition increases grain yield, which, in turn, exerts a feed-forward stimulation of photosynthetic rates via enhanced mesophyll conductance and alters primary metabolism in rice. New Phytol. 196, 752-762. doi: 10.1111/j.1469-8137.2012.04299.x

Deus, A. C. F., de Mello Prado, R., de Cássia Félix Alvarez, R., de Oliveira, R. L. L., and Felisberto, G. (2020). Role of silicon and salicylic acid in the mitigation of nitrogen deficiency stress in rice plants. Silicon. 12, 997-1005. doi: 10.1007/s12633-019-00195-5 
Dishon, M., Zohar, O., and Sivan, U. (2011). Effect of cation size and charge on the interaction between silica surfaces in 1:1,2:1, and 3:1 aqueous electrolytes. Langmuir 27, 12977-12984. doi: 10.1021/la202533s

Doncheva, S., Poschenrieder, C., Stoyanova, Z., Georgieva, K., Velichkova, M., and Barceló, J. (2009). Silicon amelioration of manganese toxicity in Mn-sensitive and Mn-tolerant maize varieties. Environ. Exp. Bot. 65, 189-197. doi: 10.1016/j. envexpbot.2008.11.006

dos Santos Sarah, M. M., de Mello Prado, R., Teixeira, G. C. M., de Souza Júnior, J. P., de Medeiros, R. L. S., and Barreto, R. F. (2021). Silicon supplied via roots or leaves relieves potassium deficiency in maize plants. Silicon doi: 10.1007/ s12633-020-00908-1

dos Santos, M. S., Sanglard, L., Martins, S. C. V., Barbosa, M. L., de Melo, D. C., Gonzaga, W. F., et al. (2019). Silicon alleviates the impairments of iron toxicity on the rice photosynthetic performance via alterations in leaf diffusive conductance with minimal impacts on carbon metabolism. Plant Physiol. Biochem. 143, 275-285. doi: 10.1016/j.plaphy.2019.09.011

Dragisic-Maksimovic, J., Mojovic, M., Maksimovic, V., Romheld, V., and Nikolic, M. (2012). Silicon ameliorates manganese toxicity in cucumber by decreasing hydroxyl radical accumulation in the leaf apoplast. J. Exp. Bot. 63, 2411-2420. doi: $10.1093 /$ jxb/err359

Dufey, I., Mathieu, A. S., Draye, X., Lutts, S., and Bertin, P. (2014). Construction of an integrated map through comparative studies allows the identification of candidate regions for resistance to ferrous iron toxicity in rice. Euphytica 203, 59-69. doi: 10.1007/s10681-014-1255-5

Epstein, E. (1994). The anomaly of silicon in plant biology. Proc. Nat. Acad. Sci. U.S.A. 91, 11-17. doi: 10.1073/pnas.91.1.11

Epstein, E. (1999). Silicon. Ann. Rev. Plant Physiol. Plant Mol. Biol. 50, 641-664. doi: 10.1146/annurev.arplant.50.1.641

Epstein, E., and Bloom, A. J. (2008). Mineral Nutrition of Plants: Principles and Perspectives, 2nd Edn. Sunderland: Sinauer Associations.

Esteban, R., Ariz, I., Cruz, C., and Moran, J. F. (2016). Review: mechanisms of ammonium toxicity and the quest for tolerance. Plant Sci. 248, 92-101. doi: 10.1016/j.plantsci.2016.04.008

Exley, C., and Birchall, J. D. (1992). Hydroxyaluminosilicate formation in solutions of low total aluminum concentration. Polyhedron 11, 1901-1907. doi: 10.1016/ S0277-5387(00)83738-9

Exley, C., and Birchall, J. D. (1993). A mechanism of hydroxyaluminosilicate formation. Polyhedron 12, 1007-1017. doi: 10.1016/S0277-5387(00)87177-6

Fan, X., Wen, X., Huang, F., Cai, Y., and Cai, K. (2016). Effects of silicon on morphology, ultrastructure and exudates of rice root under heavy metal stress. Acta Physiol. Plant. 38:197. doi: 10.1007/s11738-016-2221-8

Feng, Y., Li, X., Guo, S., Chen, X., Chen, T., He, Y., et al. (2019). Extracellular silica nanocoat formed by layer-by-layer (LBL) self-assembly confers aluminum resistance in root border cells of pea (Pisum sativum). J. Nanobiotechnol. 17:53. doi: 10.1186/s12951-019-0486-y

Flam-Shepherd, R., Huynh, W. Q., Coskun, D., Hamam, A. M., Britto, D. T., and Kronzucker, H. J. (2018). Membrane fluxes, bypass flows, and sodium stress in rice: the influence of silicon. J. Exp. Bot. 69, 1679-1692. doi: 10.1093/jxb/erx460

Fleck, A. T., Schulze, S., Hinrichs, M., Specht, A., Wassmann, F., Schreiber, L., et al. (2015). Silicon promotes exodermal casparian band formation in Siaccumulating and $\mathrm{Si}$-excluding species by forming phenol complexes. PLoS One 10:e0138555. doi: 10.1371/journal.pone.0138555

Flora, C., Khandekar, S., Boldt, J., and Leisner, S. (2019). Silicon alleviates long-term copper toxicity and influences gene expression in Nicotiana tabacum. J. Plant Nutr. 42, 864-878. doi: 10.1080/01904167.2019.1589508

Frazāo, J. J., Prado, R. d., de Souza Junior, J. P., and Rossatto, D. R. (2020). Silicon changes C:N:P stoichiometry of sugarcane and its consequences for photosynthesis, biomass partitioning and plant growth. Sci. Rep. 10:12492.

Fu, Y. Q., Shen, H., Wu, D. M., and Cai, K. Z. (2012). Silicon-mediated amelioration of $\mathrm{Fe}^{2+}$ toxicity in rice (Oryza sativa L.) roots. Pedosphere 22, 795-802. doi: 10.1016/S1002-0160(12)60065-4

Gattullo, C. E., Allegretta, I., Medici, L., Fijan, R., Pii, Y., Cesco, S., et al. (2016). Silicon dynamics in the rhizosphere: connections with iron mobilization. J. Plant Nutr. Soil Sci. 179, 409-417. doi: 10.1002/jpln.201500535

Głazowska, S. E. (2018). Plant Cell Walls: Interactions With Nitrogen Supply and Silicon Deposition in Brachypodium Distachyon and Wheat. Ph.D. thesis. Copenhagen: Faculty of Science, University of Copenhagen.
Gong, H. J. Randall, P. D., and Flowers, T. J. (2006). Silicon deposition in the root reduces sodium uptake in rice (Oryza sativa L.) seedlings by reducing bypass flow. Plant Cell Environ. 29, 1970-1979. doi: 10.1111/j.1365-3040.2006.01572

Gonzalo, M. J., Lucena, J. J., and Hernaindez-Apaolaza, L. (2013). Effect of silicon addition on soybean (Glycine max) and cucumber (Cucumis sativus) plants grown under iron deficiency. Plant Physiol. Biochem. 70, 455-461. doi: 10.1016/ j.plaphy.2013.06.007

Gottardi, S., Iacuzzo, F., Tomasi, N., Cortella, G., Manzocco, L., Pinton, R., et al. (2012). Beneficial effects of silicon on hydroponically grown corn salad (Valerianella locusta (L.) Laterr) plants. Plant Physiol. Biochem. 56, 14-23. doi: 10.1016/j.plaphy.2012.04.002

Gou, T., Yang, L., Hu, W., Chen, X., Zhu, Y., Guo, J., et al. (2020). Silicon improves the growth of cucumber under excess nitrate stress by enhancing nitrogen assimilation and chlorophyll synthesis. Plant Physiol. Biochem. 152, 53-61. doi: 10.1016/j.plaphy.2020.04.031

Greger, M., Landberg, T., and Vaculík, M. (2018). Silicon influences soil availability and accumulation of mineral nutrients in various plant species. Plants 7:41. doi: 10.3390/plants7020041

Gu, H. H., Zhan, S. S., Wang, S. Z., Tang, Y. T., Chaney, R. L., Fang, X. H., et al. (2012). Silicon-mediated amelioration of zinc toxicity in rice (Oryza sativa L.) seedlings. Plant Soil 350, 193-204. doi: 10.1007/s11104-011-0894-8

Gunes, A., Inal, A., Bagci, E. G., and Pilbeam, D. J. (2007). Silicon-mediated changes of some physiological and enzymatic parameters symptomatic for oxidative stress in spinach and tomato grown in sodic-B toxic soil. Plant Soil 290, 103-114. doi: 10.1007/s11104-006-9137-9

Gunes, A., Kadioglu, Y. K., Pilbeam, D. J., Inal, A., Coban, S., and Aksu, A. (2009). Influence of silicon on sunflower cultivars under drought stress II: essential and non essential element uptake determined by polarized energy dispersive X-ray fluorescence. Commun. Soil Sci. Plant Analysis 39, 1904-1927. doi: 10.1080/00103620802134719

Gunes, A., Pilbeam, D. J., Inal, A., and Coban, S. (2008). Influence of silicon on sunflower cultivars under drought stress 1: growth antioxidant mechanisms and lipid peroxidation. Commun. Soil Sci. Plant Analysis 39, 1885-1903. doi: 10.1080/00103620802134651

Haddad, C., Arkoun, M., Jamois, F., Schwarzenberg, A., Yvin, J. C., Etienne, P., et al. (2018). Silicon promotes growth of Brassica napus L. and delays leaf senescence induced by nitrogen starvation. Front. Plant Sci. 9:516. doi: 10.3389/fpls.2018. 00516

Herandez-Apaolaza, L. (2014). Can silicon partially alleviate micronutrient deficiency in plants? A review. Planta 240, 447-458. doi: 10.1007/s00425-0142119-x

Hernández-Apaolaza, L., Escribano, L., Zamarreno, A. M., Garcia-Mina, J. M., Cano, C., and Carrasco-Gil, S. (2020). Root silicon addition induces Fe deficiency in cucumber plants, but facilitates their recovery after Fe resupply. A comparison with si foliar sprays. Front. Plant Sci. 11:580552. doi: 10.3389/ fpls.2020.580552

Hinrichs, M., Fleck, A. T., Biedermann, E., Ngo, N. S., Schreiber, L., and Schenk, M. K. (2017). An ABC transporter is involved in the silicon-induced formation of Casparian bands in the exodermis of rice. Front. Sci. 8:671. doi: 10.3389/fpls. 2017.00671

Hodson, M. J., and Evans, D. E. (2020). Aluminium-silicon interactions in higher plants: an update. J. Exp. Bot. 71, 6719-6729. doi: 10.1093/jxb/eraa024

Hodson, M. J., and Sangster, A. G. (1993). The interaction between silicon and aluminium in Sorghum bicolor (L.) moench: growth analysis and X-ray microanalysis. Ann. Bot. 72, 389-400. doi: 10.1006/anbo.1993. 1124

Hodson, M. J., and Wilkins, D. A. (1991). Localization of aluminium in the roots of Norway spruce [Picea abies (L.) Karst.] inoculated with Paxillus involutus Fr. New Phytol. 118, 273-278. doi: 10.1111/j.1469-8137.1991.tb00 977.x

Hoffmann, J., Berni, R., Hausman, J.-F., and Guerriero, G. (2020). A review on the beneficial role of silicon against salinity in non-accumulator crops: tomato as a model. Biomolecules 10, 1284. doi: 10.3390/biom 10091284

Hömberg, A., Obst, M., Knorr, H.-K., Kalbitz, K., and Schaller, J. (2020). Increased silicon concentration in fen peat leads to a release of iron and phosphate and changes in the composition of dissolved organic matter. Geoderma 374, 114422. doi: 10.1016/j.geoderma.2020.114422 
Horiguchi, T. (1988). Mechanism of manganese toxicity and tolerance of plants. IV. Effects of silicon on alleviation of manganese toxicity of rice plants. Soil Sci. Plant Nutr. 34, 65-73. doi: 10.1080/00380768.1988.10415580

Horiguchi, T., and Morita, S. (1987). Mechanism of manganese toxicity and tolerance of plants. IV. Effect of silicon on alleviation of manganese toxicity of barley. J. Plant Nutr. 10, 2299-2310. doi: 10.1080/00380768.1988.104 15580

Hosseini, S. A., Maillard, A., Hajirezaei, M. R., Ali, N., Schwarzenberg, A., Jamois, F., et al. (2017). Induction of barley silicon transporter HvLsil and HvLsi2, increased silicon concentration in the shoot and regulated starch and ABA homeostasis under osmotic stress and concomitant potassium deficiency. Front. Plant Sci. 8:1359. doi: 10.3389/fpls.2017.01359

Hosseini, S. A., Naseri Rad, S., Ali, N., and Yvin, J. C. (2019). The ameliorative effect of silicon on maize plants grown in Mg-deficient conditions. Int. J. Mol. Sci. 20, 969. doi: 10.3390/ijms20040969

Hu, A. Y., Che, J., Shao, J. F., Yokosho, K., Zhao, X. Q., Shen, R. F., et al. (2018). Silicon accumulated in the shoots results in down-regulation of phosphorus transporter gene expression and decrease of phosphorus uptake in rice. Plant Soil. 423, 317-325. doi: 10.1007/s11104-017$3512-6$

Hu, A. Y., Xu, S. N., Qin, D. N., Li, W., and Zhao, X. Q. (2021). Role of silicon in mediating phosphorus imbalance in plants. Plants 10:51. doi: 10.3390/ plants10010051

Huang, S., and Ma, J. F. (2020). Silicon suppresses zinc uptake through downregulating zinc transporter gene in rice. Physiol. Plant. 170, 580-591. doi: 10. $1111 /$ ppl.13196

Iwasaki, K., and Matsumura, A. (1999). Effect of silicon on alleviation of manganese toxicity in pumpkin (Cucurbita moschata Duch cv. Shintosa). Soil Sci. Plant Nutr. 45, 909-920. doi: 10.1080/00380768.1999.10414340

Iwasaki, K., Maier, P., Fecht, M., and Horst, W. J. (2002). Leaf apoplastic silicon enhances manganese tolerance of cowpea (Vigna unguiculata). J. Plant Physiol. 159, 167-173. doi: 10.1078/0176-1617-00691

Jang, S. W., Kim, Y., Khan, A. L., Na, C. I., and Lee, I. J. (2018). Exogenous short-term silicon application regulates macro-nutrients, endogenous phytohormones, and protein expression in Oryza sativa L. BMC Plant Biol. 18:4. doi: 10.1186/s12870-017-1216-y

Katz, O., Puppe, D., Kaczorek, D., Prakash, N. B., and Schaller, J. (2021). Silicon in the soil-plant continuum: intricate feedback mechanisms within ecosystems. Plants 10:652. doi: 10.3390/plants10040652

Kaya, C., Tuna, A. L., Guneri, M., and Ashraf, M. (2011). Mitigation effects of silicon on tomato plants bearing fruit grown at high boron levels. J. Plant Nutr. 34, 1985-1994. doi: 10.1080/01904167.2011.610485

Kaya, C., Tuna, A. L., Sonmez, O., Ince, F., and Higgs, D. (2009). Mitigation effects of silicon on maize plants grown at high zinc. J. Plant Nutr. 32, 1788-1798. doi: 10.1080/01904160903152624

Kaya, C., Tuna, L., and Higgs, D. (2006). Effect of silicon on plant growth and mineral nutrition of maize grown under water-stress conditions. J. Plant Nutr. 29, 1469-1480. doi: 10.1080/01904160600837238

Keller, C., Rizwan, M., Davidian, J. C., Pokrovsky, O. S., Bovet, N., Chaurand, P., et al. (2015). Effect of silicon on wheat seedlings (Triticum turgidum L.) grown in hydroponics and exposed to 0 to $30 \mathrm{mM} \mathrm{Cu}$. Planta 241, 847-860. doi: 10.1007/s00425-014-2220-1

Khaliq, A., Ali, S., Hameed, A., Farooq, M. A., Farid, M., Shakoor, M. B., et al. (2016). Silicon alleviates nickel toxicity in cotton seedlings through enhancing growth, photosynthesis, and suppressing $\mathrm{Ni}$ uptake and oxidative stress. Arch. Agron. Soil Sci. 62, 633-647. doi: 10.1080/03650340.2015.10 73263

Khandekar, S., and Leisner, S. (2011). Soluble silicon modulates expression of Arabidopsis thaliana genes involved in copper stress. J. Plant Physiol. 168, 699-705. doi: 10.1016/j.jplph.2010.09.009

Kiba, T., Kudo, T., Kojima, M., and Sakakibara, H. (2011). Hormonal control of nitrogen acquisition: roles of auxin, abscisic acid, and cytokinin. J. Exp. Bot. 62, 1399-1409. doi: 10.1093/jxb/erq410

Kim, Y. H., Khan, A. L., Kim, D. H., Lee, S., Kim, K. M., Waqas, M., et al. (2014). Silicon mitigates heavy metal stress by regulating P-type heavy metal ATPases, Oryza sativa low silicon genes, and endogenous phytohormones. BMC Plant. Boil. 14:13. doi: 10.1186/1471-2229-14-13
Kinrade, S. D., Del Nin, J. W., Schach, A. S., Sloan, T. A., Wilson, K. L., and Knight, C. T. G. (1999). Stable five- and six-coordinated silicate anions in aqueous solution. Science 285, 1542-1545. doi: 10.1126/science.285.5433.1542

Kopittke, P. M., Gianoncelli, A., Kourousias, G., Green, K., and McKenna, B. A. (2017). Alleviation of al toxicity by $\mathrm{Si}$ is associated with the formation of $\mathrm{Al}-\mathrm{Si}$ complexes in root tissues of sorghum. Front. Sci. 8:2189. doi: 10.3389/fpls.2017. 02189

Kostic, L., Nikolic, N., Bosnic, D., Samardzic, J., and Nikolic, M. (2017). Silicon increases phosphorus (P) uptake by wheat under low $\mathrm{P}$ acid soil conditions. Plant Soil. 419, 447-455. doi: 10.1007/s11104-017-3364-0

Laine, P., Haddad, C., Arkoun, M., Yvin, J. C., and Etiene, P. (2019). Silicon promotes agronomic performance in Brassica napus cultivated under field conditions with two nitrogen fertilizer inputs. Plants (Basel) 8:137. doi: 10.3390/ plants 8050137

Lazard, M., Blanquet, S., Fisicaro, P., Labarraque, G., and Plateau, P. (2010). Uptake of selenite by Saccharomyces cerevisiae involves the high and low affinity orthophosphate transporters. J. Biol. Chem. 285, 32029-32037. doi: 10.1074/jbc. M110.139865

Li, H.-F., McGrath, S. P., and Zhao, F.-J. (2008). Selenium uptake, translocation and speciation in wheat supplied with selenate or selenite. New Phytol. 178, 92-102. doi: 10.1111/j.1469-8137.2007.02343.x

Li, J., Leisner, M., and Frantz, J. (2008). Alleviation of copper toxicity in Arabidopsis thaliana by silicon addition to hydroponic solutions. J. Am. Soc. Hortic. Sci. 133, 70-77. doi: 10.21273/JASHS.133.5.670

Li, M., Wang, Q., Liu, Z., Pan, X., and Zhang, Y. (2019). Silicon application and related changes in soil bacterial community dynamics reduced ginseng black spot incidence in Panax ginseng in a short-term study. BMC Microbiol. 19:263. doi: 10.1186/s12866-019-1627-z

Li, P., Song, A., Li, Z., Fan, F., and Liang, Y. (2012). Silicon ameliorates manganese toxicity by regulating manganese transport and antioxidant reactions in rice (Oryza sativa L.). Plant Soil 354, 407-419. doi: 10.1007/s11104-011$1076-4$

Li, P., Song, A., Li, Z., Fan, F., and Liang, Y. (2015). Silicon ameliorates manganese toxicity by regulating both physiological processes and expression of genes associated with photosynthesis in rice (Oryza sativa L.). Plant Soil 397, 289-301. doi: 10.1007/s11104-015-2626-y

Li, Y. C., Sumner, M. E., Miller, W. P., and Alva, A. K. (1996). Mechanism of silicon induced alleviation of aluminum phytotoxicity. J. Plant Nutr. 19, 1075-1087. doi: 10.1080/01904169609365181

Liang, Y. (1999). Effects of silicon on enzyme activity and sodium, potassium and calcium concentration in barley under salt stress. Plant Soil 209, 217-224. doi: 10.1023/A:1004526604913

Liang, Y., and Ding, R. (2002). Influence of silicon on microdistribution of mineral ions in roots of salt-stressed barley as associated with salt tolerance in plants. Sci. China Life Sci. 45, 298. doi: 10.1360/02yc9033

Liang, Y., Nikolic, M., Bélanger, R., Gong, H., and Song, A. (2015). Silicon in Agriculture: From Theory to Practice. Dordrecht: Springer.

Liang, Y., and Shen, Z. (1994). Interaction of silicon and boron in oilseed rape plants. J. Plant Nutr. 17, 415-425. doi: 10.1080/01904169409364736

Liang, Y., Chen, Q., Liu, Q., Zhang, W., and Ding, R. (2003). Exogenous silicon (Si) increases antioxidant enzyme activity and reduces lipid peroxidation in roots of salt-stressed barley (Hordeum vulgare L.). J. Plant Physiol. 160, 1157-1164. doi: 10.1078/0176-1617-01065

Liang, Y., Sun, W., Zhu, Y.-G., and Christie, P. (2007). Mechanisms of siliconmediated alleviation of abiotic stresses in higher plants: a review. Environ. Pollut. 147, 422-428. doi: 10.1016/j.envpol.2006.06.008

Liang, Y., Zhang, W., Chen, Q., and Ding, R. (2005). Effects of silicon on $\mathrm{H}^{+}$ATPase and $\mathrm{H}^{+}$-PPase activity, fatty acid composition and fluidity of tonoplast vesicles from roots of salt-stressed barley (Hordeum vulgare L.). Environ. Exp. Bot. 53, 29-37. doi: 10.1016/j.envexpbot.2004.02.010

Ma, J. F. (2004). Role of silicon in enhancing the resistance of plants to biotic and abiotic stresses. J. Soil Sci. Plant Nutr. 50, 11-18. doi: 10.1080/00380768.2004. 10408447

Ma, J. F., and Takahashi, E. (1990). Effect of silicon on the growth and phosphorus uptake of rice. Plant Soil. 126, 115-119. doi: 10.1007/bf00041376

Ma, J. F., and Takahashi, E. (1993). Interaction between calcium and silicon in water-cultured rice plants. Plant Soil. 148, 107-113. doi: 10.1007/bf02185390 
Ma, J. F., Sasaki, M., and Matsumoto, H. (1997). Al-induced inhibition of root elongation in corn, Zea mays L. is overcome by Si addition. Plant Soil 188, 171-176. doi: 10.1023/A:1004274223516

Mabagala, F. S., Geng, Y. H., Cao, G. J., Wang, L. C., Wang, M., and Zhang, M. L. (2020). Effect of silicon on crop yield, and nitrogen use efficiency applied under straw return treatments. Appl. Ecol. Environ. Res. 18, 5577-5590. doi: 10.15666/aeer/1804_55775590

Maillard, A., Ali, N., Schwarzenberg, A., Jamois, F., Yvin, J.-C., and Hosseini, S. A. (2018). Silicon transcriptionally regulates sulfur and ABA metabolism and delays leaf senescence in barley under combined sulfur deficiency and osmotic stress. Environ. Exp. Bot. 155, 394-410. doi: 10.1016/j.envexpbot.2018.07.026

Mali, M., and Aery, N. C. (2008a). Silicon effects on nodule growth, dry-matter production, and mineral nutrition of cowpea (Vigna unguiculata). J. Plant Nutr. Soil Sci. 171, 835-840. doi: 10.1002/jpln.200700362

Mali, M., and Aery, N. C. (2008b). Influence of silicon on growth, relative water contents and uptake of silicon, calcium and potassium in wheat grown in nutrient solution. J. Plant Nutr. 31, 1867-1876. doi: 10.1080/ 01904160802402666

Malta, P. G., Arcanjo-Silva, S., Ribeiro, C., Campos, N. V., and Azevedo, A. A. (2016). Rudgea viburnoides (Rubiaceae) overcomes the low soil fertility of the Brazilian Cerrado and hyperaccumulates aluminum in cell walls and chloroplasts. Plant Soil 408, 369-384. doi: 10.1007/s11104-016-2926-x

Mandlik, R., Thakral, V., Raturi, G., Shinde, S., Nikolic, M., Tripathi, D. K., et al. (2020). Significance of silicon uptake, transport, and deposition in plants. J. Exp. Bot. 71, 6703-6718. doi: 10.1093/jxb/eraa301

Markovich, O., Steiner, E., Kouril, S., Tarkowski, P., Aharoni, A., and Elbaum, R. (2017). Silicon promotes cytokinin biosynthesis and delays senescence in Arabidopsis and Sorghum. Plant Cell Environ. 40, 1189-1196. doi: 10.1111/pce. 12913

Marschner, H. (2012). Marschner's Mineral Nutrition of Higher Plants, 3rd Edn, ed. P. Marschner (London: Academic Press).

Marschner, H., Oberle, H., Cakmak, I., and Römheld, V. (1990). Growth enhancement by silicon in cucumber (Cucumis sativus) plants depends on imbalance in phosphorus and zinc supply. Plant Soil 124, 211-219. doi: 10. 1007/bf00009262

Masarovič, D., Slováková, L', Bokor, B., Bujdoš, M., and Lux, A. (2012). Effect of silicon application on Sorghum bicolor exposed to toxic concentration of zinc. Biologia 67, 706-712. doi: 10.2478/s11756-012-0054-5

Mateos-Naranjo, E., Galle, A., Florez-Sarasa, I., Perdomo, J. A., Galmes, J., RibasCarbo, M., et al. (2015). Assessment of the role of silicon in the Cu-tolerance of the C4 grass Spartina densiflora. J. Plant Physiol. 178, 74-83. doi: 10.1016/j. jplph.2015.03.001

Mehrabanjoubani, P., Abdolzadeh, A., Sadeghipour, H. R., and Aghdasi, M. (2015). Silicon affects transcellular and apoplastic uptake of some nutrients in plants. Pedosphere 25, 192-201. doi: 10.1016/S1002-0160(15)60004-2

Mengel, K., and Kirkby, E. A. (2001). Principles of Plant Nutrition, 5th Edn. Dordrecht: Kluwer Academic Publishers.

Miao, B. H., Han, X. G., and Zhang, W. H. (2010). The ameliorative effect of silicon on soybean seedlings grown in potassium-deficient medium. Ann. Bot. 105, 967-973. doi: 10.1093/aob/mcq063

Minden, V., Schaller, J., and Olde Venterink, H. (2020). Plants increase silicon content as a response to nitrogen or phosphorus limitation: a case study with Holcus lanatus. Plant Soil. 462, 95-108. doi: 10.1007/s11104-02004667-1

Mitani, N., Chiba, Y., Yamaji, N., and Ma, J. F. (2009). Identification and characterization of maize and barley Lsi2-like silicon efflux transporters reveals a distinct silicon uptake system from that in rice. Plant Cell. 21, 2133-2142. doi: $10.1105 /$ tpc. 109.067884

Mitani-Ueno, N., and Ma, J. F. (2020). Linking transport system of silicon with its accumulation in different plant species. Soil Sci. Plant Nutr. 20, 1-8. doi: 10.1080/00380768.2020.1845972

Mitani-Ueno, N., Yamaji, N., and Ma, J. F. (2016). High silicon accumulation in the shoot is required for down-regulating the expression of si transporter genes in rice. Plant Cell Physiol. 57, 2510-2518. doi: 10.1093/pcp/pcw163

Mitani-Ueno, N., Yamaji, N., Zhao, F.J., and Ma, J.F. (2011). The aromatic/arginine selectivity filter of NIP aquaporins plays a critical role in substrate selectivity for silicon, boron, and arsenic. J. Exp. Bot. 62, 4391-4398. doi: 10.1093/jxb/err158
Miwa, K., and Fujiwara, T. (2010). Boron transport in plants: co-ordinated regulation of transporters. Ann. Bot. 105, 1103-1108. doi: 10.1093/aob/ mcq044

Miyake, Y., and Takahashi, E. (1985). Effect of silicon on the growth of soybean plants in a solution culture. Soil Sci. Plant Nutr. 31, 625-636. doi: 10.1080/ 00380768.1985.10557470

Miyake, Y., and Takahashi, E. (1986). Effect of silicon on the growth and fruit production of strawberry plants in a solution culture. Soil Sci. Plant Nutr. 32, 321-326. doi: 10.1080/00380768.1986.10557510

Nable, R. O., Lance, R. C. M., and Cartwright, B. (1990). Uptake of boron and silicon by barley genotypes with differing susceptibilities to boron toxicity. Ann. Bot. 66, 83-90. doi: 10.1093/oxfordjournals.aob.a088003

Nardini, A., Grego, F., Trifilò, P., and Salleo, S. (2010). Changes of xylem sap ionic content and stem hydraulics in response to irradiance in Laurus nobilis. Tree Physiol. 30, 628-635. doi: 10.1093/jxb/err348

Neu, S., Schaller, J., and Dudel, E. G. (2017). Silicon availability modifies nutrient use efficiency and content, C:N:P stoichiometry, and productivity of winter wheat (Triticum aestivum L.). Sci Rep. 7:40829. doi: 10.1038/srep40829

Neumann, D., Zur Nieden, U., Schwieger, W., Leopold, I., and Lichtenberger, O. (1997). Heavy metal tolerance of Minuartia verna. J. Plant Physiol. 151, 101-108. doi: 10.1016/S0176-1617(97)80044-2

Nikolic, D. B., Nesic, S., Bosnic, D., Kostic, L., Nikolic, M., and Samardzic, J. T. (2019). Silicon alleviates iron deficiency in barley by enhancing expression of strategy II genes and metal redistribution. Front. Plant Sci 10:416. doi: 10.3389/ fpls.2019.00416

Nikolic, M., Nikolic, N., Kostic, L., Pavlovic, J., Bosnic, P., Stevic, N., et al. (2016). The assessment of soil availability and wheat grain status of zinc and iron in Serbia: Implications for human nutrition. Sci. Total Environ. 553, 141-148. doi: 10.1016/j.scitotenv.2016.02.102

Noronha, H., Silva, A., Mitani-Ueno, N., Conde, C., Sabir, F., Prista, C., et al. (2020). The grapevine NIP2;1 aquaporin is a silicon channel. J. Exp. Bot. 71, 6789-6798. doi: $10.1093 / \mathrm{jxb} / \mathrm{eraa} 294$

Nowakowski, W., and Nowakowska, J. (1997). Silicon and copper interaction in the growth of spring wheat seedlings. Biol. Plant. 3, 463-466. doi: 10.1023/A: 1001009100026

Nozawa, S., Sato, T., and Otake, T. (2018). Effect of dissolved silica on immobilization of boron by magnesium oxide. Minerals 8:76. doi: 10.3390/ $\min 8020076$

Okuda, A., and Takahashi, E. (1962). Effect of silicon supply on the injuries due to excessive amounts of $\mathrm{Fe}, \mathrm{Mn}, \mathrm{Cu}, \mathrm{As}, \mathrm{Al}$, Co of barley and rice plant. Jpn. J. Soil Sci. Plant Nutr 33, 1-8.

Oliva, S. R., Mingorance, M. D., and Leidi, E. O. (2011). Effects of silicon on copper toxicity in Erica andevalensis Cabezudo and Rivera: a potential species to remediate contaminated soils. J. Environ. Monit. 13, 591-596. doi: 10.1039/ c0em00549e

Owino-Gerroh, C., and Gascho, G. J. (2005). Effect of silicon on low pH soil phosphorus sorption and on uptake and growth of maize. Commun. Soil Sci. Plant Anal. 35, 2369-2378. doi: 10.1081/lcss-200030686

Pascual, M. B., Echevarria, V., Gonzalo, M. J., and Hernandez-Apaolaza, L. (2016). Silicon addition to soybean (Glycine max L.) plants alleviate zinc deficiency. Plant Physiol. Biochem. 108, 132-138. doi: 10.1016/j.plaphy.2016.07.008

Pati, S., Pal, B., Badole, S., Hazra, G. C., and Mandal, B. (2016). Effect of silicon fertilization on growth, yield, and nutrient uptake of rice. Commun. Soil Sci. Plant Anal. 47, 284-290. doi: 10.1080/00103624.2015.1122797

Pavlovic, J., Samardzic, J., Kostic, L., Laursen, K. H., Natic, M., Timotijevic, G., et al. (2016). Silicon enhances leaf remobilization of iron in cucumber under limited iron conditions. Ann. Bot. 118, 271-280. doi: 10.1093/aob/mcw105

Pavlovic, J., Samardzic, J., Maksimovic, V., Timotijevic, G., Stevic, N., Laursen, K. H., et al. (2013). Silicon alleviates iron deficiency in cucumber by promoting mobilization of iron in the root apoplast. New Phytol. 198, 1096-1107. doi: 10.1111/nph.12213

Pontigo, S., Godoy, K., Jiménez, H., Gutiérrez-Moraga, A., Mora, M. d. 1. L., and Cartes, P. (2017). Silicon-mediated alleviation of aluminum toxicity by modulation of $\mathrm{Al} / \mathrm{Si}$ uptake and antioxidant performance in ryegrass plants. Front. Plant Sci. 8:642. doi: 10.3389/fpls.2017.00642

Prabagar, S., Hodson, M. J., and Evans, D. E. (2011). Silicon amelioration of aluminium toxicity and cell death in suspension cultures of Norway spruce 
(Picea abies (L.) Karst.). Environ. Exp. Bot. 70, 266-276. doi: 10.1016/j. envexpbot.2010.10.001

Reithmaier, G.-M. S., Knorr, K.-H., Arnhold, S., Planer-Friedrich, B., and Schaller, J. (2017). Enhanced silicon availability leads to increased methane production, nutrient and toxicant mobility in peatlands. Sci. Rep. 7:8728. doi: 10.1038/ s41598-017-09130-3

Réthoré, E., Ali, N., Yvin, J. C., and Hosseini, S. A. (2020). Silicon regulates source to sink metabolic homeostasis and promotes growth of rice plants under sulfur deficiency. Int. J. Mol. Sci. 21, 3677. doi: 10.3390/ijms21103677

Reynolds, O. L., Keeping, M. G., and Meyer, J. H. (2009). Silicon-augmented resistance of plants to herbivorous insects: a review. Ann. Appl. Biol. 155, 171-186. doi: 10.1111/j.1744-7348.2009.00348.x

Rogalla, H., and Römheld, V. (2002a). Role of leaf apoplast in silicon-mediated manganese tolerance of Cucumis sativus L. Plant Cell Environ. 25, 549-555. doi: 10.1046/j.1365-3040.2002.00835.x

Rogalla, H., and Römheld, V. (2002b). "Effects of silicon on the availability of boron," in Boron in Plant and Animal Nutrition, eds H. Goldbach, B. Rerkasem, M. A. Wimmer, P. H. Brown, M. Thellier, and R. W. Bell (Boston, MA: Springer), 205-211. doi: 10.1007/978-1-4615-0607-2_19

Rowatt, E., and Williams, R. J. P. (1996). The interaction of aluminium with silicic acid in the presence and absence of a phosphorylated protein. Coord. Chem. Rev. 149, 167-177. doi: 10.1016/S0010-8545(96)90022-3

Saqib, M., Zörb, C., and Schubert, S. (2008). Silicon-mediated improvement in the salt resistance of wheat (Triticum aestivum) results from increased sodium exclusion and resistance to oxidative stress. Funct. Plant Biol. 35, 633-639. doi: 10.1071/FP08100

Sarasketa, A., Gonzalez-Moro, M. B., Gonzalez-Murua, C., and Marino, D. (2014). Exploring ammonium tolerance in a large panel of Arabidopsis thaliana natural accessions. J. Exp. Bot. 65, 6023-6033. doi: 10.1093/jxb/eru342

Schaller, J., Brackhage, C., Gessner, M. O., Bauker, E., and Gert Dudel, E. (2012). Silicon supply modifies C:N:P stoichiometry and growth of Phragmites australis. Plant Biol. (Stuttg) 14, 392-396. doi: 10.1111/j.1438-8677.2011. 00537.x

Schaller, J., Faucherre, S., Joss, H., Obst, M., Goeckede, M., Planer-Friedrich, B., et al. (2019). Silicon increases the phosphorus availability of Arctic soils. Sci. Rep. 9:449. doi: 10.1038/s41598-018-37104-6

Schaller, J., Puppe, D., Kaczorek, D., Ellerbrock, R., and Sommer, M. (2021). Silicon cycling in soils revisited. Plants 10:295. doi: 10.3390/plants10020295

Schnurbusch, T., Hayes, J., Hrmova, M., Baumann, U., Ramesh, S. A., Tyerman, S. D., et al. (2010). Boron toxicity tolerance in barley through reduced expression of the multifunctional aquaporin HvNIP2; 1. Plant Physiol. 153, 1706-1715. doi: 10.1104/pp.110.158832

Sheng, H., Ma, J., Pu, J., and Wang, L. (2018). Cell wall-bound silicon optimizes ammonium uptake and metabolism in rice cells. Ann. Bot. 122, 303-313. doi: 10.1093/aob/mcy068

Shi, Y., Wang, Y., Flowers, T. J., and Gong, H. (2013). Silicon decreases chloride transport in rice (Oryza sativa L.) in saline conditions. J. Plant Physiol. 170, 847-853. doi: 10.1016/j.jplph.2013.01.018

Soltani, M., Kafi, M., Nezami, A., and Taghiyari, H. R. (2017). Effects of silicon application at nano and micro scales on the growth and nutrient uptake of potato minitubers (Solanum tuberosum var. Agria) in greenhouse conditions. BioNanoScience 8, 218-228. doi: 10.1007/s12668-017-0467-2

Song, A., Li, P., Fan, F., Li, Z., and Liang, Y. (2014). The effect of silicon on photosynthesis and expression of its relevant genes in rice (Oryza sativa L.) under high-zinc stress. PLoS One 9:113782. doi: 10.1371/journal.pone.0113782

Song, A., Li, P., Li, Z., Fan, F., Nikolic, M., and Liang, Y. (2011). The alleviation of zinc toxicity by silicon is related to zinc transport and antioxidative reactions in rice. Plant Soil 344, 319-333. doi: 10.1007/s11104-011-0749-3

Soratto, R. P., Fernandes, A. M., Pilon, C., and Souza, M. R. (2019). Phosphorus and silicon effects on growth, yield, and phosphorus forms in potato plants. J. Plant Nutr. 42, 218-233. doi: 10.1080/01904167.2018.1554072

Soylemezoglu, G., Demir, K., Inal, A., and Gunes, A. (2009). Effect of silicon on antioxidant and stomatal response of two grapevine (Vitis vinifera L.) rootstocks grown in boron toxic, saline and boron toxic-saline soil. Sci. Hort. 123, 240-246. doi: 10.1016/j.scienta.2009.09.005

Sreenivasan, A. (1934). The Role of silicon in plant nutrition. Curr. Sci. 3, 193-197.

Stevic, N., Korac, J., Pavlovic, J., and Nikolic, M. (2016). Binding of transition metals to monosilicic acid in aqueous and xylem (Cucumis sativus L.) solutions: a low-T electron paramagnetic resonance study. BioMetals 29, 945-951. doi: 10.1007/s10534-016-9966-9

Sun, H., Duan, Y., Mitani-Ueno, N., Che, J., Jia, J., Liu, J., et al. (2020). Tomato roots have a functional silicon influx transporter but not a functional silicon efflux transporter. Plant Cell Environ. 43, 732-744. doi: 10.1111/pce. 13679

Tegeder, M., and Masclaux-Daubresse, C. (2017). Source and sink mechanisms of nitrogen transport and use. New Phytol. 217, 35-53. doi: 10.1111/nph.14876

Teixeira, G. C. M., de Mello Prado, R., Oliveira, K. S., D’Amico-Damião, V., and da Silveira Sousa Junior, G. (2020). Silicon increases leaf chlorophyll content and iron nutritional efficiency and reduces iron deficiency in sorghum plants. J. Soil Sci. Plant Nutr. 20, 1311-1320. doi: 10.1007/s42729-020-00214-0

Viciedo, O. D., de Mello Prado, R., Lizcano Toledo, R., dos Santos, L. C. N., Calero Hurtado, A., Nedd, L. L. T., et al. (2019). Silicon supplementation alleviates ammonium toxicity in sugar beet (Beta vulgaris L.). J. Plant. Nutr. Soil Sci. 19, 413-419. doi: 10.1007/s42729-019-00043-w

Vieira da Cunha, K. P., Williams Araújo do Nascimento, C., and José da Silva, A. (2008). Silicon alleviates the toxicity of cadmium and zinc for maize (Zea mays L.) grown on a contaminated soil. J. Plant Nutr. Soil Sci. 171, 849-853. doi: 10.1002/jpln.200800147

Wang, M., Yang, W., Zhou, F., Du, Z., Xue, M., Chen, T., et al. (2019). Effect of phosphate and silicate on selenite uptake and phloem-mediated transport in tomato (Solanum lycopersicum L.). Environ. Sci. Pollut. Res. 26, 20475-20484. doi: 10.1007/s11356-019-04717-x

Wang, Y., Krogstad, T., Clarke, J. L., Hallama, M., Ogaard, A. F., Eich-Greatorex, S., et al. (2016). Rhizosphere organic anions play a minor role in improving crop species' ability to take up residual phosphorus $(\mathrm{P})$ in agricultural soils low in $\mathrm{P}$ availability. Front. Plant Sci. 7:1664. doi: 10.3389/fpls.2016.01664

Weng, L. P., Lexmond, T. M., Wolthoorn, A., Temminghoff, E. J. M., and Van Riemsdijk, W. H. (2003). Phytotoxicity and bioavailability of nickel: chemical speciation and bioaccumulation. Environ. Toxicol. Chem. 22, 2180-2187. doi: 10.1897/02-116

White, P. J., and Broadley, M. R. (2001). Chloride in soils and its uptake and movement within the plant: a review. Ann. Bot. 88, 967-988. doi: 10.1006/anbo. 2001.1540

Williams, D. E., and Vlamis, J. (1957). The effect of silicon on yield and manganese54 uptake and distribution in the leaves of barley grown in culture solutions. Plant Physiol. 32, 404-409. doi: 10.1104/pp.32.5.404

Wu, X., Yu, Y., Baerson, S. R., Song, Y., Liang, G., Ding, C., et al. (2017). Interactions between nitrogen and silicon in rice and their effects on resistance toward the brown planthopper Nilaparvata lugens. Front. Plant Sci. 8:28. doi: 10.3389/fpls.2017.00028

Xiao, Z., Yan, G., Ye, M., and Liang, Y. (2021). Silicon relieves aluminum-induced inhibition of cell elongation in rice root apex by reducing the deposition of aluminum in the cell wall. Plant Soil 21, 1-17. doi: 10.1007/s11104-02104850-y

Xu, C. X., Ma, Y. P., and Liu, Y. L. (2015). Effects of silicon (Si) on growth, quality and ionic homeostasis of aloe under salt stress. S. Afr. J. Bot. 98, 26-36. doi: 10.1016/j.sajb.2015.01.008

Yamaji, N., and Ma, J. F. (2011). Further characterization of a rice silicon efflux transporter, Lsi2. Soil Sci. Plant Nutr. 57, 259-264. doi: 10.1080/00380768.2011. 565480

Yan, G., Fan, X., Tan, L., Yin, C., Li, T., and Liang, Y. (2021a). Root silicon deposition and its resultant reduction of sodium bypass flow is modulated by OsLsil and OsLsi2 in rice. Plant Physiol. Biochem. 158, 219-227. doi: 10.1016/j. plaphy.2020.11.015

Yan, G., Fan, X., Zheng, W., Gao, Z., Yin, C., Li, T., et al. (2021b). Silicon alleviates salt stress-induced potassium deficiency by promoting potassium uptake and translocation in rice (Oryza sativa L.). J. Plant Physiol. 21:153379. doi: 10.1016/ j.jplph.2021.153379

Yan, G., Nikolic, M., Ye, M., Xiao, Z., and Liang, Y. (2018). Silicon acquisition and accumulation in plant and its significance for agriculture. J. Integr. Agric. 17, 2138-2150. doi: 10.1016/S2095-3119(18)62037-4

Yeo, A. R., Flowers, S. A., Rao, G., Welfare, K., Senanayake, N., and Flowers, T. J. (1999). Silicon reduces sodium uptake in rice (Oryza sativa L.) in saline conditions and this is accounted for by a reduction in the transpirational bypass flow. Plant Cell Environ. 22, 559-565. doi: 10.1046/j.1365-3040.1999. 00418.x 
Zhang, W., Liu, D., Li, C., Cui, Z., Chen, X., Russell, Y., et al. (2015). Zinc accumulation and remobilization in winter wheat as affected by phosphorus application. Field Crops Res. 184, 155-161. doi: 10.1016/j.fcr.2015.10.002

Zhang, Y., Liang, Y., Zhao, X., Jin, X., Hou, L., Shi, Y., et al. (2019). Silicon compensates phosphorus deficit-induced growth inhibition by improving photosynthetic capacity, antioxidant potential, and nutrient homeostasis in tomato. Agronomy 9:733. doi: 10.3390/agronomy911 0733

Zhao, X. Q., Mitani, N., Yamaji, N., Shen, R. F., and Ma, J. F. (2010). Involvement of silicon influx transporter OsNIP2;1 in selenite uptake in rice. Plant Physiol. 153, 1871-1877. doi: 10.1104/pp.110.157867

Zhou, X., Yang, J., Kronzucker, H. J., and Shi, W. (2020). Selenium biofortification and interaction with other elements in plants: a review. Front. Plant Sci. 11:586421. doi: 10.3389/fpls.2020.5864
Zwieniecki, M. A., Melcher, P. J., and Michele Holbrook, N. M. (2001). Hydrogel control of xylem hydraulic resistance in plants. Science 291, 1059-1062. doi: $10.1126 /$ science. 1057175

Conflict of Interest: The authors declare that the research was conducted in the absence of any commercial or financial relationships that could be construed as a potential conflict of interest.

Copyright (c) 2021 Pavlovic, Kostic, Bosnic, Kirkby and Nikolic. This is an open-access article distributed under the terms of the Creative Commons Attribution License (CC BY). The use, distribution or reproduction in other forums is permitted, provided the original author(s) and the copyright owner(s) are credited and that the original publication in this journal is cited, in accordance with accepted academic practice. No use, distribution or reproduction is permitted which does not comply with these terms. 